\title{
Purchase Analysis Based on the Relationship Between Customers and Service Providers
}

\author{
Yuya Miyamoto, Michiko Tsubaki \\ The University of Electro-Communications, Tokyo, Japan
}

\begin{abstract}
Although the service industry takes up a large percentage in world economies and is situated in the center of all industries, it has been pointed out that its growth rate is smaller compared to the other industries, which is partly because of its characteristic features: "amorphousness", "simultaneity", and "heterogeneity". Service providers are therefore required to be experienced and have a good business sense to succeed in this field. The aim of this research is to support those who are not experienced or do not have a good business sense, using scientific approach. This research tries to present recommendation, taking customers' value and compatibilities with employees into account, and is based on the assumption that customers and employees have one-to-one contact over a period. A total of 3,447 customers and 133 employees were classified according to their philosophies, needs, and abilities. For each case, customers' purchase histories are first interrelated with the result of questionnaire, and put purchase behavior into marketing using Bayesian network. Then the HUB was examined and extracted features of the data of the questionnaire, and executed the stochastic inference to present the recommendation. This procedure enabled us to extract the features of customers' purchase behavior, and it is turned out that compatibilities of customers and employees are more important than the difference of their values and abilities.
\end{abstract}

Keywords: heterogeneous, customer values, recommendation, service science, purchase Bayesian network, stochastic reasoning

\section{Introduction}

The service sector's importance is increasing in the global economy; further, the number of countries is also increasing in which the ratio of their GDP involving the service sector has surpassed $70 \%$.

A strategic frame work known as the Service Triangle shows the importance for long term succeeding to keep the balance between the Company (Management), Employees (Service providers), and Customers (Zeithaml, Bitner, \& Gremler, 2010). The relationship between service providers and customers is called the interactive marketing. The interactive marketing is to deliver the company's services. That is why the interactive marketing is one of the most important factors to make the relationship better with customers.

The differences exist in not only customers, but also service providers (Zeithaml, Parasuraman, \& Berry, 1985; Grönroos, 1990). Therefore, services' quality and productivity depend on the service providers' experiences and intuitions. Service providers' heterogeneity is a factor in the gap between previous

Yuya Miyamoto, graduate student, Department of Informatics, The University of Electro-Communications, Tokyo, Japan.

Michiko Tsubaki, professor, Department of Informatics, The University of Electro-Communications, Tokyo, Japan.

Correspondence concerning this article should be addressed to Michiko Tsubaki, 1-5-1 Chofugaoka, Chofu, Tokyo 182-8585, Japan. 
expectations and the actual service provided (Zeithaml, Berry, \& Parasuraman, 1993). The customisation and promotion of efficiency is a trade-off relationship (Anderson, Fornell, \& Rust, 1997). Further, this tends to be stronger in the service industry than in the manufacturing industry.

This study aims the proposal of analytical method to promote the efficient purchases based on the heterogeneity between customers and service providers' in the interactive marketing.

\section{Literature Review}

As a study pointing to the interactive marketing in the service triangle, service marketing practices explain how value-creating interactions between service providers and customers are more transparent than usual (Hultman \& Ek, 2011). However, they did not quantitatively analyse the interaction between customers and service providers. As a study focusing on the service providers in the service triangle, there is the paper which analyses service providers' motivations (Gąsior, Skowron, \& Sak-Skowron, 2014). It is considered that service providers' motivation along with their satisfaction with work is one of the most significant factors determining functioning and the success of an organization on the market. The service providers' satisfaction must relate with customers. However, they did not analyse the relationship based on the heterogeneity between service providers and customers. These studies do not discuss whether customer satisfaction depends on service providers' heterogeneity in customisation.

\section{Research Methods}

This study comprehends the structure of customers' consumption and use through a factor analysis of questionnaire survey data regarding their sense of values, lifestyle, consumption, and use. Customers are then classified using factor scores. Furthermore, this study also interprets the structure of service providers' sales behaviours using a factor analysis of the questionnaire survey data regarding their sense of values, motivations, and abilities; service providers are then classified using factor scores. Additionally, a sales-purchase Bayesian network, which demonstrates the relationship between the questionnaire survey regarding their sense of values, needs, and so forth, and their purchase history, with products and services in each combination of customer and service provider types, is analysed. The study then investigates the significant gap in purchase probabilities, as conditioned by customers' positive and negative responses to each questionnaire in the purchase Bayesian network, as characteristics of the type's sales. The sales promotion support method is proposed by comparing the purchase probability predicted for all service providers in the type to the purchase probability predicted for a service provider in the type.

The 1st section of next chapter will provide an analysis of customer purchases and use, constructed through a factor analysis based on their sense of values, lives, purchase, and use. They will be classified using a factor score resulting from this factor analysis. The 2nd section of next chapter will analyse service providers' sales activities through a factor analysis based on their sense of values, motivation, and abilities, and will classify them by the factor score resulting from this factor analysis. Each type's characteristics will be investigated. In the 3rd section of next chapter, according to the combination of customer and service provider types resulting from the factor analysis, a sales-purchase Bayesian network model to further analyse the relationship between such questionnaire items as sense of values, needs, and feelings from lives, and service sales data, will be analysed. Then sales-purchase activities' characteristics based on combinations of customer and service provider types will be compared, and confirm that obvious differences exist when each 
provider type corresponds to each consumer type. Then a sales and purchase analysis to improve the usage value, and promote sales by combining customer and service provider types, will be proposed, and verify its usefulness. Additionally, the chapter of conclusion will discuss each service provider's sales Bayesian network by calculating the differences between purchase probabilities using the stochastic reasoning predictive for customers who react to each questionnaire item positively, negatively, and respectively. Further, whether the questionnaire items with greater differences which are characteristic of service provider-type sales will be investigated. Subsequently, the Bayesian network for each service providers' sales, as included in the type, will be analysed, and the purchase probability will be calculated using similar stochastic reasoning. The combinations of questionnaire items and services that each provider does not sell, in spite of the result that other service providers in the type can sell to customers with positive reactions, will be focused on. Then a support system for service providers by listing the services that focus on the above-mentioned questionnaire items using the predicted purchase probabilities to improve their sales, will be proposed.

\section{Analysis and Research Result}

\section{Classificaton of Customer Based on Their Sense of Values and Consuming and Use}

Questionnaire survey for customers. Customers were surveyed using a questionnaire to understand the structure of their consumption and use based on such factors as their sense of values, their daily life, needs, and brand royalty. These survey items are based on (Watabe \& Tsubaki, 2016) consumption and use hypothesis model.

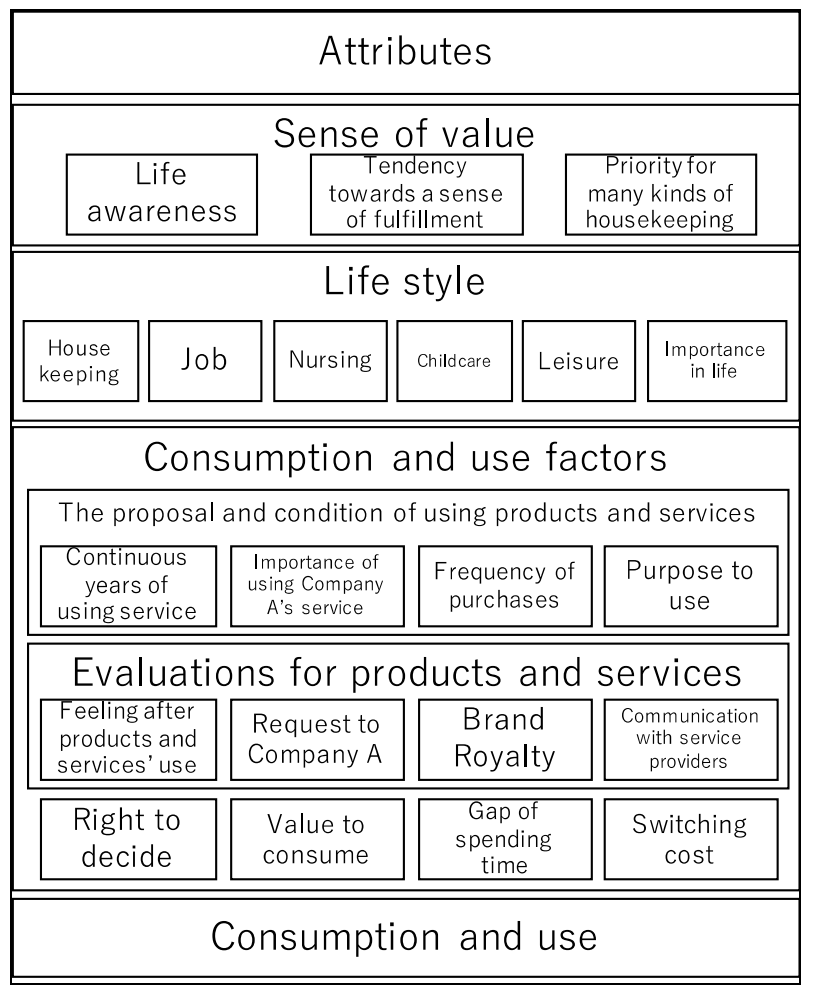

Figure 1. Hypothesis model of consumption and use.

According to Figure 1, "Attributes", such as a customer's age and families, act as a fundamental base for consumption and use. Next fundamental factor is assumed to be a "sense of value" that is determined by such 
questions involving "life awareness", "tendency towards a sense of fulfilment", and "priority for many kinds of housekeeping". Additionally, in their lives the ratios of five items, such as "housekeeping", "job", "nursing", "childcare", and "leisure", are based on their sense of values; "importance in life" builds their "lifestyle", and their "daily life" enables us to observe the customer's condition. As consumption and use factors, "the proposal and condition of using products and services" should be measured by "continuous years of using the service", "importance of using Company A's service", "frequency of purchases", and "the purpose of use". Further, "evaluations for products and services" should be measured by "feeling after products and services' use", "request to Company A", "brand loyalty", and "communication with service provider". Finally, they consider "right to decide", "value to consume", "gap of spending time", and "switching cost". Finally, "purchase behaviour" will occur.

This survey targets customers with service providers at Office I in Company A.

The questionnaire is summarised as follows:

Target: Current customers, or 7,948 participants who live in City I and are purchasing products and services from Company A.

Effective answers: 3,447 (43.37\%).

Purpose: To understand customers' needs and sense of values, and confirm obvious factors regarding customer consumption and usage; to improve the quality of products and services; and to increase the numbers of both new and repeat customers.

Time period: 2015/07/09-2015/10/30

Classification of customer based on the structure of consumption and use for each customer value type. The questionnaire survey data were analysed through factor analyses (using a principal factor method, promax rotation, and parallel analysis criteria) as the same conditions which are to reduce variables in which the factor loading is less than 0.4 and more than 0.4 in two factors, and repeat the factor analysis until each variable's factor loading becomes more than 0.4 in one factor (Shinkawa, Shimada, Hayase, \& Inui, 2009; Ono \& Shoji, 2015; Watabe \& Tsubaki, 2016). At the repeated fourth result, seven factor structures are adopted through parallel analysis criteria.

Table 1 illustrates the parallel analysis result, and Table 2 displays the factor loadings for seven factor structures.

Table 1

Units for Properties With Parallel Analysis

\begin{tabular}{lllll}
\hline & Eigenvalue & Parallel analysis & Contribution Rate & Cumulative contribution ratio \\
\hline 1st factor & 5.443 & 1.162 & 20.20 & 20.20 \\
2nd factor & 3.153 & 1.138 & 11.70 & 31.80 \\
3rd factor & 2.329 & 1.123 & 8.63 & 40.50 \\
4th factor & 2.029 & 1.111 & 7.52 & 48.00 \\
5th factor & 1.841 & 1.097 & 6.82 & 54.80 \\
6th factor & 1.432 & 1.083 & 5.30 & 60.10 \\
7th factor & 1.144 & 1.070 & 4.24 & 64.30 \\
8th factor & 0.942 & 1.058 & 3.49 & 67.80 \\
9th factor & 0.824 & 1.048 & 3.05 & 70.90 \\
10th factor & 0.761 & 1.037 & 2.82 & 73.70 \\
\hline
\end{tabular}


Table 2

Factor Loadings (Customers' Questionnaire Data)

\begin{tabular}{|c|c|c|c|c|c|c|c|c|}
\hline Category & Questionnaire outline & $\begin{array}{l}1 \text { st } \\
\text { factor }\end{array}$ & $\begin{array}{l}\text { 2nd } \\
\text { factor }\end{array}$ & $\begin{array}{l}\text { 3rd } \\
\text { factor }\end{array}$ & $\begin{array}{l}4 \text { th } \\
\text { factor }\end{array}$ & $\begin{array}{l}5 \text { th } \\
\text { factor }\end{array}$ & $\begin{array}{l}\text { 6th } \\
\text { factor }\end{array}$ & $\begin{array}{l}7 \text { th } \\
\text { factor }\end{array}$ \\
\hline Lifestyle & Time of raising children & 0.001 & 0.003 & 1.330 & 0.058 & 0.003 & 0.069 & 0.011 \\
\hline \multirow{4}{*}{$\begin{array}{l}\text { Evaluation of } \\
\text { housekeeping }\end{array}$} & Cooking & 0.029 & 0.828 & 0.021 & 0.048 & 0.014 & 0.017 & 0.002 \\
\hline & Washing & 0.016 & 0.874 & 0.008 & 0.028 & 0.001 & 0.022 & 0.018 \\
\hline & Cleaning up & 0.019 & 0.827 & 0.002 & 0.034 & 0.005 & 0.023 & 0.031 \\
\hline & Shopping & 0.007 & 0.742 & 0.012 & 0.040 & 0.009 & 0.016 & 0.038 \\
\hline \multirow{8}{*}{$\begin{array}{l}\text { Evaluation of } \\
\text { products and } \\
\text { services }\end{array}$} & Spending time with better feeling & 0.531 & 0.013 & 0.009 & 0.004 & 0.008 & 0.039 & 0.056 \\
\hline & Quality of products and services & 0.490 & -0.018 & 0.007 & 0.041 & 0.012 & 0.074 & 0.047 \\
\hline & Convenience & 0.514 & 0.019 & 0.037 & 0.007 & 0.005 & 0.016 & 0.007 \\
\hline & Attachment to products and services & 0.810 & 0.001 & -0.038 & 0.025 & 0.052 & 0.045 & 0.021 \\
\hline & Trust of products and services & 0.816 & 0.013 & 0.005 & 0.086 & 0.016 & 0.033 & 0.040 \\
\hline & Recommendation & 0.698 & 0.010 & 0.026 & 0.101 & 0.016 & 0.063 & 0.018 \\
\hline & Evaluation from close people & 0.693 & 0.007 & 0.025 & 0.003 & 0.000 & 0.042 & 0.043 \\
\hline & Good products, although expensive & 0.720 & 0.026 & 0.004 & 0.036 & 0.012 & 0.079 & 0.005 \\
\hline \multirow{2}{*}{ Consumption value } & Focus on convenience & 0.009 & 0.016 & 0.057 & 0.020 & 0.014 & 0.816 & 0.037 \\
\hline & Focus on after service & 0.047 & 0.003 & 0.066 & 0.034 & 0.022 & 0.891 & 0.043 \\
\hline \multirow{2}{*}{ Decision right } & Decision right to low price & 0.052 & 0.034 & 0.021 & 0.026 & 0.038 & 0.041 & 0.786 \\
\hline & Decision right to high price & 0.017 & 0.024 & 0.008 & 0.001 & 0.051 & 0.049 & 0.640 \\
\hline \multirow{5}{*}{ Demand for Company A } & Enjoy with family & 0.082 & 0.005 & 0.030 & 0.612 & 0.017 & 0.028 & 0.014 \\
\hline & $\begin{array}{l}\text { Explaining how to use products and } \\
\text { services }\end{array}$ & 0.042 & 0.013 & 0.126 & 0.569 & 0.072 & 0.073 & 0.001 \\
\hline & Delivery service & 0.015 & 0.003 & 0.054 & 0.647 & 0.044 & 0.031 & 0.041 \\
\hline & One-point lesson & 0.073 & 0.021 & 0.059 & 0.736 & 0.022 & 0.009 & 0.054 \\
\hline & Organisation lecture & 0.091 & 0.006 & 0.098 & 0.699 & 0.046 & 0.059 & 0.014 \\
\hline \multirow{3}{*}{ Communication } & $\begin{array}{l}\text { Communication based on daily } \\
\text { conversation }\end{array}$ & 0.079 & 0.016 & 0.021 & 0.022 & 0.446 & 0.022 & 0.005 \\
\hline & Communication based on sales products & 0.030 & 0.005 & 0.001 & 0.011 & 0.980 & 0.014 & 0.009 \\
\hline & Communication based on new products & -0.021 & -0.005 & -0.007 & -0.007 & 0.945 & -0.003 & 0.004 \\
\hline \multirow[b]{2}{*}{ Attributes } & Number of preschool children & 0.031 & 0.052 & 0.442 & 0.087 & 0.009 & 0.046 & 0.006 \\
\hline & $\begin{array}{l}\text { Number of elementary and junior high } \\
\text { school students }\end{array}$ & 0.003 & 0.057 & 0.464 & 0.092 & 0.018 & 0.105 & 0.010 \\
\hline
\end{tabular}

The extracted seven factor structures were then interpreted, and their names were investigated. The first factor was named "loyalty caused by realising the feeling from using products and services" due to high factor loadings for "feeling and satisfaction" and "brand loyalty". The second factor was named "the families' evaluation for housekeeping" because "life awareness" expressed a high factor loading in families' evaluation for housekeeping. The third factor was named "time pressure by childcare" because there were high factor loadings for childcare time in "priority for housekeeping" and the numbers of preschool, primary, and junior high school students in "attributes" are high. The fourth factor is constructed only as "request for Company A", and named "request for housekeeping products and services". The fifth factor is constructed using only "communication with service providers", and named "communication to promote customers' consumption". The sixth factor is constructed using only "a sense of values for consumption" and named "selection criterion of housekeeping products and services". The seventh factor is constructed using only the "right to decide", and named "right to decide". Table 3 states the results. 
Table 3

Factor's Name (Customer Questionnaire)

1st Factor (Contribution Rate: $20.2 \%$ )

1st factor

Loyalty caused by realising feelings from using products and services Spend time with better feelings

Quality of products and service

Convenience

Attachment to products and services

Trust of products and services

Recommendation

Evaluation from close people

Good products, even expensive

2nd Factor (Contribution Rate: 11.7\%)

\begin{tabular}{lll}
\hline & 2nd factor & \\
\hline The families' housekeeping evaluation & & Factor loadings \\
\hline Cooking & Housekeeping evaluation & 0.828 \\
Washing & Housekeeping evaluation & 0.874 \\
Cleaning up & Housekeeping evaluation & 0.827 \\
Shopping & Housekeeping evaluation & 0.742 \\
\hline
\end{tabular}

3rd Factor (Contribution Rate: $8.63 \%$ )

\begin{tabular}{lll}
\hline \multicolumn{2}{l}{ 3rd factor } & \\
\hline Time pressure by childcare & & Factor loadings \\
\hline Time in raising children & Priority for housekeeping & 1.33 \\
The number of preschool children & Attribute & 0.442 \\
The number of elementary, junior high school students & Attribute & 0.464 \\
\hline 4th Factor (Contribution Rate: $7.52 \%)$ & \\
\hline
\end{tabular}

4th Factor (Contribution Rate: $7.52 \%$ )

\begin{tabular}{lll}
\hline \multicolumn{2}{l}{ 4th factor } & \\
\hline Request for housekeeping products and services & Factor loadings \\
\hline Enjoy with family & Demand to Company A & 0.612 \\
Explaining how to use products and services & Demand to Company A & 0.569 \\
Delivery service & Demand to Company A & 0.647 \\
One point lesson & Demand to Company A & 0.736 \\
Organisation lecture & Demand to Company A & 0.699 \\
\hline
\end{tabular}

5th Factor (Contribution Rate: $6.82 \%$ )

\begin{tabular}{lll}
\hline \multicolumn{2}{l}{ Communication to promote customer consumption } & 5th factor \\
\hline Communication based on daily conversation & Communication & Factor loadings \\
Communication based on sales products & Communication & 0.446 \\
Communication based on new products & Communication & 0.98 \\
\hline
\end{tabular}

6th Factor (Contribution Rate: 5.30\%)

\begin{tabular}{|c|c|c|}
\hline \multicolumn{3}{|c|}{ 6th factor } \\
\hline Selection criterion of $h$ & ervices & Factor loadings \\
\hline Focus on convenience & Sense of values for consumption & 0.816 \\
\hline Focus on after service & Sense of values for Consumption & 0.891 \\
\hline
\end{tabular}


7th Factor (Contribution Rate: $4.24 \%$ )

\begin{tabular}{lll}
\hline & \multicolumn{1}{c}{ 7th factor } & Factor loadings \\
\hline Right to decide & Decision right & 0.786 \\
\hline Right to decide on low price & Decision right & 0.64 \\
Right to decide on high price & \\
\hline
\end{tabular}

Customers are then classified into types by Ward's clustering method, based on the factor analysis scores. Table 4 illustrates the number and average of each type's factor scores, with five to seven cluster members, which are compared to determine the number of types.

Table 4

The Result of Customer Clustering (the Number of Clusters 5-7)

5 Clusters

\begin{tabular}{llllll}
\hline Factor & Group 1 & Group 2 & Group 3 & Group 4 & Group 5 \\
\hline 1st factor & 0.404 & -0.703 & 0.011 & 0.256 & -0.393 \\
2nd factor & 0.618 & 0.002 & -0.091 & -0.969 & 0.020 \\
3rd factor & -0.606 & -0.503 & 3.164 & -0.725 & -0.454 \\
4th factor & 0.045 & -0.580 & 0.510 & 0.278 & -0.271 \\
5th factor & 0.440 & -0.229 & 0.187 & 0.226 & -2.217 \\
6th factor & 0.433 & -0.716 & -0.379 & 0.390 & -0.040 \\
7th factor & 0.224 & -0.484 & -0.172 & 0.263 & 0.104 \\
Number of people & 1,161 & 779 & 544 & 696 & 267 \\
\hline
\end{tabular}

6 Clusters

\begin{tabular}{lllllll}
\hline Factor & Group 1 & Group 2 & Group 3 & Group 4 & Group 5 & Group 6 \\
\hline 1st factor & 0.973 & -0.703 & 0.011 & 0.256 & -0.058 & -0.393 \\
2nd factor & 0.572 & 0.002 & -0.091 & -0.969 & 0.656 & 0.020 \\
3rd factor & -0.615 & -0.503 & 3.164 & -0.725 & -0.599 & -0.454 \\
4th factor & 0.559 & -0.580 & 0.510 & 0.278 & -0.372 & -0.271 \\
5th factor & 0.455 & -0.229 & 0.187 & 0.226 & 0.427 & -2.217 \\
6th factor & 0.785 & -0.716 & -0.379 & 0.390 & 0.149 & -0.040 \\
7th factor & 0.241 & -0.484 & -0.172 & 0.263 & 0.210 & 0.104 \\
Number of people & 520 & 779 & 544 & 696 & 641 & 267
\end{tabular}

7 Clusters

\begin{tabular}{llllllll}
\hline Factor & Group 1 & Group 2 & Group 3 & Group 4 & Group 5 & Group 6 & Group 7 \\
\hline 1st factor & 0.973 & -0.703 & -0.026 & 0.256 & 0.048 & -0.058 & -0.393 \\
2nd factor & 0.572 & 0.002 & -0.106 & -0.969 & -0.076 & 0.656 & 0.020 \\
3rd factor & -0.615 & -0.503 & 4.485 & -0.725 & 1.833 & -0.599 & -0.454 \\
4th factor & 0.559 & -0.580 & 0.572 & 0.278 & 0.447 & -0.372 & -0.271 \\
5th factor & 0.455 & -0.229 & 0.087 & 0.226 & 0.288 & 0.427 & -2.217 \\
6th factor & 0.785 & -0.716 & -0.499 & 0.390 & -0.257 & 0.149 & -0.040 \\
7th factor & 0.241 & -0.484 & -0.111 & 0.263 & -0.232 & 0.210 & 0.104 \\
Number of people & 520 & 779 & 273 & 696 & 271 & 641 & 267 \\
\hline
\end{tabular}

Table 4 divides types 1 of 5 clusters into types 1 and 5 of 6 clusters. Table 5 compares their characteristics of types 1 and 5. The first, fourth, and sixth factors are then divided into high and middle characteristics; 
therefore, it is appropriate to divide them into six clusters. Additionally, type 3 of 6 clusters is divided into type 3 and 5 of 7 clusters. These are divided into high and middle-high in the fourth factor, and middle-low and middle in the sixth factor, but they are similar conclusions. There should be six clusters then decided. Table 6 shows the detailed characteristics in the case of six clusters, which comprehensively evaluate the averages of factor scores for each type (factor scores are distributed with standard normal distribution, and are then evaluated as averages: less than -0.5 is low, greater than 0.5 is high, and in between is middle), median of factor score for each type (the same criteria, with using averages), the ratio of the number of people (evaluated as low when the ratio of less than -0.5 is the largest, and high when the ratio of greater than 0.5 is the largest, and middle when the ratio in between is the largest). These are then comprehensively evaluated in five grades: high, middle-high, middle, low-middle, and low. For example, if the average, median, and ratio of the number of people are high, middle, middle, its evaluation is middle-high.

Table 5

\section{Customers' Characteristics Based on Each Cluster Number}

5 Clusters

\begin{tabular}{llllll}
\hline & Type 1 & Type 2 & Type 3 & Type 4 & Type 5 \\
\hline 1st factor & Middle & Low & Middle & Middle & Low-middle \\
2nd factor & High & Middle & Middle & Low & Middle \\
3rd factor & Low & Low & High & Low & Middle \\
4th factor & Middle & Low & High & Middle & Middle \\
5th factor & Middle-high & Middle & Middle-high & Middle & Low \\
6th factor & Middle-high & Low & Middle & Middle-high & Middle \\
7th factor & Middle & Middle & Middle & Middle & Middle \\
\hline
\end{tabular}

6 Clusters

\begin{tabular}{|c|c|c|c|c|c|c|}
\hline & Type 1 & Type 2 & Type 3 & Type 4 & Type 5 & Type 6 \\
\hline 1st factor & High & Low & Middle & Middle & Middle & Low-middle \\
\hline 2nd factor & High & Middle & Middle & Low & High & Middle \\
\hline 3rd factor & Low & Low & High & Low & Low & Middle \\
\hline 4th factor & High & Low & High & Middle & Middle & Middle \\
\hline 5 th factor & Middle-high & Middle & Middle-high & Middle & Middle-high & Low \\
\hline 6 th factor & High & Low & Middle & Middle-high & Middle & Middle \\
\hline 7 th factor & Middle & Middle & Middle & Middle & Middle & Middle \\
\hline
\end{tabular}

7 Clusters

\begin{tabular}{llllllll}
\hline & Type 1 & Type 2 & Type 3 & Type 4 & Type 5 & Type 6 & Type 7 \\
\hline 1st factor & High & Low & Middle & Middle & Middle & Middle & Low-middle \\
2nd factor & High & Middle & Middle & Low & Middle & High & Middle \\
3rd factor & Low & Low & High & Low & High & Low & Middle \\
4th factor & High & Low & High & Middle & Middle-high & Middle & Middle \\
5th factor & Middle-high & Middle & Middle-high & Middle & Middle-high & Middle-high & Low \\
6th factor & High & Low & Low-middle & Middle-high & Middle & Middle & Middle \\
7th factor & Middle & Middle & Middle & Middle & Middle & Middle & Middle \\
\hline
\end{tabular}

The characteristics resulting from the comprehensive evaluation of type in 6 clusters are displayed. 
Table 6

Characteristics of Customer Types From Comprehensive Evaluation

\begin{tabular}{|c|c|c|c|c|c|c|c|c|}
\hline 6 clusters & Factor's name & $\begin{array}{l}\text { Contribution } \\
\text { rate }\end{array}$ & Type 1 & Type 2 & Type 3 & Type 4 & Type 5 & Type 6 \\
\hline 1st factor & $\begin{array}{l}\text { Royalty caused by realizing feelings } \\
\text { from using products and services }\end{array}$ & 20.20 & High & Low & Middle & Middle & Middle & $\begin{array}{l}\text { Low- } \\
\text { middle }\end{array}$ \\
\hline 2nd factor & The families' housekeeping evaluation & 11.70 & High & Middle & Middle & Low & High & Middle \\
\hline 3rd factor & Time pressure by childcare & 8.63 & Low & Low & High & Low & Low & Middle \\
\hline 4 th factor & $\begin{array}{l}\text { Request for housekeeping products } \\
\text { and service }\end{array}$ & 7.52 & High & Low & High & Middle & Middle & Middle \\
\hline 5 th factor & $\begin{array}{l}\text { Communication to promote customer } \\
\text { consumption }\end{array}$ & 6.82 & $\begin{array}{l}\text { Middle- } \\
\text { high }\end{array}$ & Middle & $\begin{array}{l}\text { Middle- } \\
\text { high }\end{array}$ & Middle & $\begin{array}{l}\text { Middle- } \\
\text { high }\end{array}$ & Low \\
\hline 6 th factor & $\begin{array}{l}\text { Selection criterion of housekeeping } \\
\text { products and service }\end{array}$ & 5.30 & High & Low & Middle & $\begin{array}{l}\text { Middle- } \\
\text { high }\end{array}$ & Middle & Middle \\
\hline 7th factor & Right to decide & 4.24 & Middle & Middle & Middle & Middle & Middle & Middle \\
\hline \multicolumn{3}{|c|}{ Number of people } & 520 & 779 & 544 & 696 & 641 & 267 \\
\hline
\end{tabular}

Figure 2 shows histograms for attributes (age, condition of youngest child, childcare duration, and usage period of the products or services) for each type.

Each type through Table 6 and Figure 2 is interpreted, and reveals this interpretation in Table 7.

This suggests that if customer's service provider loyalty or communication is high, they will purchase Company A's products or services. These are verified as the hypothesis.

\begin{tabular}{|c|c|c|c|c|c|c|c|}
\hline \multirow{6}{*}{ Age } & $20 \mathrm{~s}$ & 0 & 4 & 18 & 4 & 0 & 0 \\
\hline & $30 \mathrm{~s}$ & 10 & 38 & 176 & 38 & 13 & 10 \\
\hline & $40 \mathrm{~s}$ & 84 & 164 & 282 & 156 & 119 & 44 \\
\hline & $50 \mathrm{~s}$ & 148 & 195 & 34 & 234 & 198 & 74 \\
\hline & $60 \mathrm{~s}$ & 157 & 222 & 25 & 155 & 193 & 84 \\
\hline & 70 s and over & 121 & 156 & 9 & 109 & 118 & 55 \\
\hline \multirow{6}{*}{$\begin{array}{c}\text { Condition of } \\
\text { youngest } \\
\text { child }\end{array}$} & preschool children & 12 & 30 & 183 & 40 & 12 & 4 \\
\hline & $\begin{array}{l}\text { elementary or junior } \\
\text { high shool students }\end{array}$ & 34 & 113 & 306 & 109 & 61 & 26 \\
\hline & \begin{tabular}{|l|} 
high shool or \\
university students
\end{tabular} & 67 & 117 & 13 & 99 & 83 & 32 \\
\hline & working people & 166 & 218 & 12 & 211 & 210 & 79 \\
\hline & $\begin{array}{l}\text { have youngest children } \\
\text { without living together }\end{array}$ & 160 & 169 & 15 & 156 & 183 & 81 \\
\hline & no children & 81 & 132 & 15 & 81 & 92 & 45 \\
\hline \multirow{6}{*}{$\begin{array}{l}\text { Average of } \\
\text { childcare } \\
\text { duration/day }\end{array}$} & no childcare time & 483 & 669 & 0 & 556 & 587 & 241 \\
\hline & under 1 hour & 7 & 34 & 10 & 68 & 18 & 11 \\
\hline & $1-3$ bours & 23 & 56 & 142 & 57 & 31 & 11 \\
\hline & $3 \sim 5$ hours & 5 & 14 & 130 & 11 & 5 & 4 \\
\hline & $5-7$ hours & 2 & 4 & 117 & 2 & 0 & 0 \\
\hline & 7 hours and over & 0 & 2 & 145 & 2 & 0 & 0 \\
\hline \multirow{6}{*}{$\begin{array}{c}\text { Usage } \\
\text { period of } \\
\text { products or } \\
\text { services }\end{array}$} & under 1 year & 15 & 29 & 47 & 22 & 20 & 14 \\
\hline & $1-4$ years & 63 & 82 & 143 & 86 & 91 & 30 \\
\hline & $4 \sim 7$ years & 62 & 92 & 94 & 100 & 67 & 32 \\
\hline & $7-10$ years & 54 & 114 & 82 & 101 & 72 & 29 \\
\hline & $10 \sim 20$ years & 185 & 263 & 135 & 223 & 216 & 82 \\
\hline & 20 years and over & 141 & 199 & 43 & 164 & 175 & 80 \\
\hline
\end{tabular}

Figure 2. Histograms of attributes on each type. 
Table 7

Interpretation of Each Type

\begin{tabular}{ll}
\hline Type & Interpretation \\
Type 1 & $\begin{array}{l}\text { In this type, "the families' evaluation for housekeeping", is high, with a strong "sense of consumption } \\
\text { values", loyalty to Company A is high, as well as communicating with service providers; having "request for } \\
\text { Company A", and "time pressures from children" are low, and their age mode is in the 60s. }\end{array}$ \\
\hline Type 2 & $\begin{array}{l}\text { This type does not have "a sense of consumption values", and loyalty to Company A is low. Therefore, } \\
\text { "request for Company A" is low; their age mode is in the 60s, including various ages. }\end{array}$ \\
\hline Type 3 & $\begin{array}{l}\text { This type has a high "request for Company A", communicates well with service providers, has nearly grown } \\
\text { children, and their age mode is in the 40s. }\end{array}$ \\
\hline Type 4 & $\begin{array}{l}\text { This type has low "families' evaluation for housekeeping", "time pressure by childcare", and their age mode } \\
\text { is in the 50s. }\end{array}$ \\
\hline Type 5 & $\begin{array}{l}\text { This type has high "families' evaluation for housekeeping", communicates fairly well with service providers, } \\
\text { "time pressure by childcare" is low, and their age mode is in the 50s and 60s. }\end{array}$ \\
\hline Type 6 & $\begin{array}{l}\text { The type has middle-low loyalty for Company A's products and services, and does not communicate with } \\
\text { service providers at all. }\end{array}$ \\
\hline
\end{tabular}

Table 8

Ranking of Evaluation Based on Each Customer's Characteristics and Ranking of Average of Purchase by Customer Type

\begin{tabular}{|c|c|c|c|c|c|c|}
\hline & Type 1 & Type 2 & Type 3 & Type 4 & Type 5 & Type 6 \\
\hline Ranking of evaluation based on each customer's characteristics & 1 & 6 & 3 & 4 & 2 & 5 \\
\hline Average of purchase (yen) & $23,395.15$ & $16,911.90$ & $18,557.98$ & $20,735.75$ & $21,105.18$ & $16,195.95$ \\
\hline Ranking of average of purchase on the customer type & 1 & 5 & 4 & 3 & 2 & 6 \\
\hline
\end{tabular}

Table 8 notes the ranked evaluation based on each customer's characteristics is similar to the ranking of average purchase by the customer type, but on types 3 and 4, and types 2 and 6 , this is reversed.

Regarding types 3 and 4, Figure 2 illustrates that type 3 includes customers who have young children and limited money. Additionally, the first factor's type characteristics are evaluated as middle. However, the average of the first factor score is 0.028 for type 3 and 0.24 for type 4; therefore, type 4 is somewhat higher. Thus, one consideration includes that type 4 would be higher on average for customers' purchases.

Regarding types 2 and 6, type 2 is evaluated lower than type 6 in almost all factors. However, type 6 is evaluated as less than 2 in the fifth factor. Therefore, another consideration exists, in that consumers' communication influences their purchasing and customers' average purchase is lower.

\section{Classificaton of Service Providers Based on Their Sense of Values and Sales}

Questionnaire survey for service providers. A questionnaire survey of service providers was conducted to understand the structure of sales-action based on a sense of career values and skills. Those survey items are based on sales actions hypothesis model (Watabe \& Tsubaki, 2016).

Figure 3 illustrates that service providers first understand consumption and use based on customers' lifestyle. They improve the fundamental competencies for workers, and acquire the specialised knowledge and skills for their products and services based on their own sense of carrier value. They then more deeply understand customers and their needs through this specialised knowledge and skills, to promote customers' consumption and improve their usage value. 


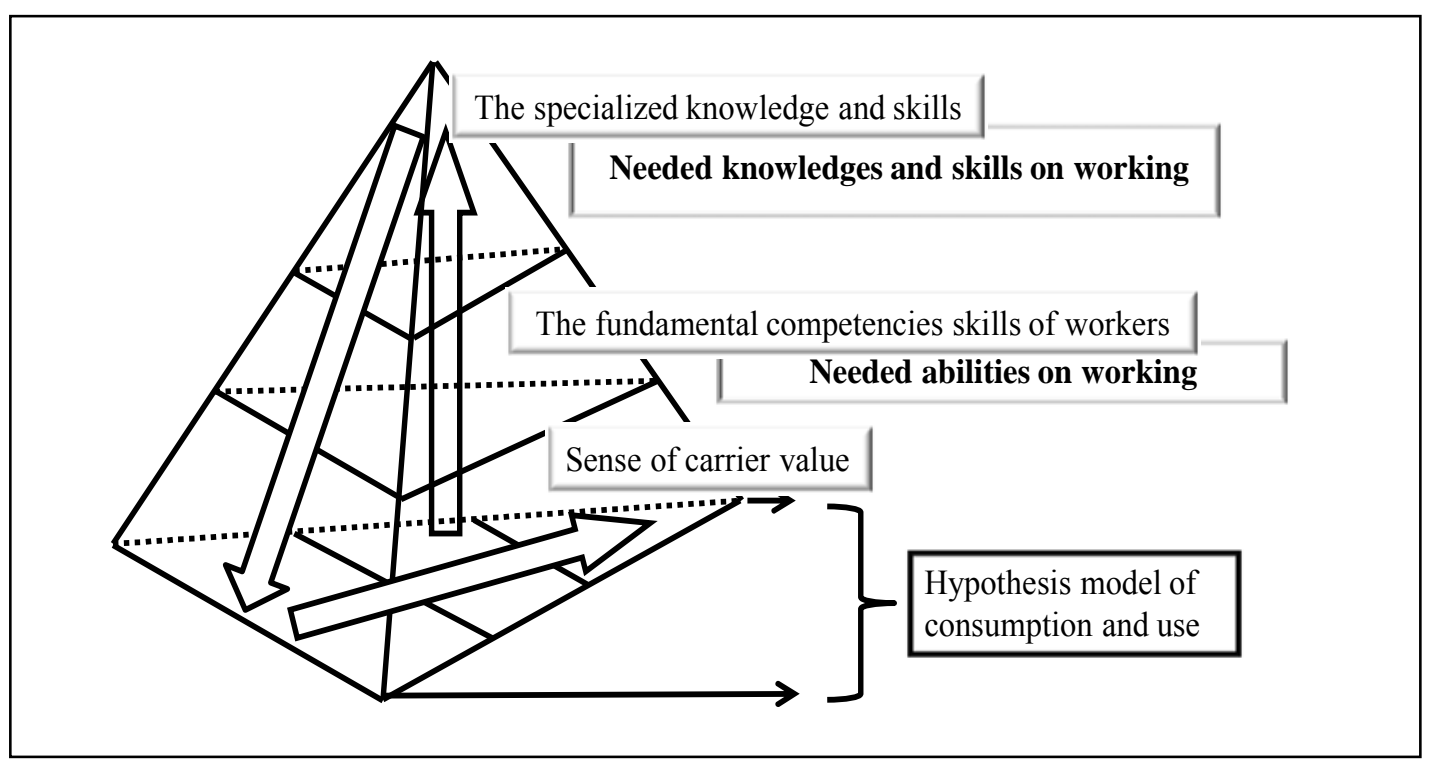

Figure 3. Sales actions hypothesis model for service providers.

The questionnaire is summarised as follows:

Target: Current service providers; 163 employees working for customers living in City I at Company A;

Effective answers: 133 participants $(81.59 \%)$;

Purpose: To confirm the important factors for service providers to understand customers' needs and sense of values, to understand service providers' sense of values and carrier values to improve the quality of use of products and services, and to increase the numbers of both new and repeat customers;

Period: 2015/07/09-2015/10/30;

Survey method: Survey by post.

Service providers' classification based on the structure of sales action. The questionnaire survey data were analysed, using the same factor analysis method and criteria as in the previous chapter, for all 91 items. Seven factor structures by parallel analysis criteria are adopted at the repeated third result. Table 9 illustrates the factor loadings for the seven factor structurers.

Table 9

Factor Loadings (Service Providers' Questionnaire Data)

\begin{tabular}{lllllllll}
\hline \multirow{2}{*}{ Category } & Questionnaire outline & $\begin{array}{l}\text { 1st } \\
\text { factor }\end{array}$ & $\begin{array}{l}\text { 2nd } \\
\text { factor }\end{array}$ & $\begin{array}{l}\text { 3rd } \\
\text { factor }\end{array}$ & $\begin{array}{l}\text { 4th } \\
\text { factor }\end{array}$ & $\begin{array}{l}5 \text { th } \\
\text { factor }\end{array}$ & $\begin{array}{l}\text { 6th } \\
\text { factor }\end{array}$ & $\begin{array}{l}\text { 7th } \\
\text { factor }\end{array}$ \\
\hline Lifestyle & Time of raising children & 0.071 & 0.109 & 0.106 & -0.048 & -0.104 & 0.083 & 1.050 \\
\hline \multirow{4}{*}{ Life awareness } & Knowledge of cooking techniques & -0.080 & -0.056 & 0.085 & 0.825 & -0.026 & -0.003 & -0.125 \\
& Knowledge of washing techniques & 0.043 & 0.011 & -0.014 & 0.794 & -0.060 & 0.007 & 0.031 \\
& Knowledge of cleaning techniques & -0.057 & 0.182 & -0.066 & 0.817 & 0.074 & -0.032 & 0.012 \\
& Knowledge of shopping techniques & -0.027 & -0.092 & 0.035 & 0.741 & 0.006 & -0.009 & 0.016 \\
& Effective cleaning, even when busy & -0.022 & -0.024 & 0.122 & 0.556 & 0.078 & 0.108 & -0.034 \\
& Self-evaluation & -0.009 & -0.252 & 0.193 & 0.062 & 0.152 & 0.453 & -0.130 \\
\hline \multirow{3}{*}{ Importance in life } & Fashion and jewellery goods & 0.154 & -0.161 & -0.165 & 0.181 & -0.109 & 0.570 & 0.223 \\
& Cosmetic items for women & 0.041 & 0.036 & -0.162 & 0.002 & 0.070 & 0.543 & 0.225 \\
& Interior & -0.067 & -0.063 & -0.043 & 0.014 & 0.076 & 0.600 & 0.026 \\
\hline
\end{tabular}


(Table 9 continued)

\begin{tabular}{|c|c|c|c|c|c|c|c|c|c|}
\hline \multirow{11}{*}{$\begin{array}{l}\text { Realizing } \\
\text { of feeling }\end{array}$} & \multirow{6}{*}{$\begin{array}{l}\text { Realizing of } \\
\text { feeling }\end{array}$} & Like to clean up & -0.024 & 0.198 & 0.680 & 0.047 & -0.066 & 0.000 & 0.025 \\
\hline & & Cleaning up, even when busy & -0.041 & 0.076 & 0.827 & 0.022 & -0.179 & -0.051 & 0.076 \\
\hline & & Becoming peaceful & -0.020 & -0.025 & 0.691 & 0.043 & 0.094 & 0.025 & 0.170 \\
\hline & & Cleaning up soon & -0.009 & -0.161 & 0.651 & 0.005 & 0.088 & 0.027 & -0.036 \\
\hline & & Spending time with better feeling & 0.004 & 0.103 & 0.693 & -0.007 & 0.050 & -0.091 & -0.015 \\
\hline & & Improving health conditions & 0.162 & 0.040 & 0.594 & -0.080 & -0.019 & 0.090 & 0.002 \\
\hline & \multirow{5}{*}{$\begin{array}{l}\text { Brand } \\
\text { loyalty }\end{array}$} & Attachment to products and services & -0.125 & 0.716 & 0.239 & 0.036 & 0.087 & 0.011 & -0.079 \\
\hline & & Trust of products and services & 0.010 & 0.628 & 0.044 & 0.036 & 0.099 & 0.004 & -0.021 \\
\hline & & Recommendation & 0.114 & 0.673 & -0.060 & -0.041 & 0.183 & -0.058 & 0.143 \\
\hline & & Good products, although expensive & -0.147 & 0.771 & -0.065 & -0.035 & 0.019 & 0.005 & 0.111 \\
\hline & & Product variety & -0.042 & 0.557 & 0.084 & -0.231 & 0.172 & -0.097 & 0.195 \\
\hline \multirow{3}{*}{$\begin{array}{l}\text { Sense of } \\
\text { values }\end{array}$} & \multirow{3}{*}{ Consumption } & Focus on quality of products and services & 0.039 & 0.241 & 0.043 & -0.155 & 0.058 & 0.563 & -0.168 \\
\hline & & Focus on convenience & -0.006 & 0.260 & 0.089 & -0.136 & -0.084 & 0.457 & -0.198 \\
\hline & & Focus on lifestyle & -0.134 & 0.069 & 0.124 & -0.071 & -0.051 & 0.589 & 0.039 \\
\hline \multirow{19}{*}{$\begin{array}{l}\text { Job about } \\
\text { Company } \\
\text { A }\end{array}$} & \multirow{4}{*}{ Motivation } & $\begin{array}{l}\text { Motivation based on appreciative } \\
\text { comments }\end{array}$ & 0.041 & 0.483 & -0.055 & 0.085 & -0.080 & 0.135 & 0.085 \\
\hline & & $\begin{array}{l}\text { Motivation based on communication } \\
\text { among service providers }\end{array}$ & 0.034 & 0.497 & -0.095 & 0.099 & 0.059 & 0.077 & -0.017 \\
\hline & & Motivation based on chance for growth & 0.045 & 0.434 & 0.079 & 0.171 & 0.317 & -0.070 & 0.123 \\
\hline & & $\begin{array}{l}\text { Motivation based on expanding own } \\
\text { knowledge }\end{array}$ & 0.191 & 0.428 & 0.013 & 0.150 & -0.174 & 0.044 & -0.037 \\
\hline & \multirow{4}{*}{$\begin{array}{l}\text { Sense of job } \\
\text { in Company } \\
\text { A }\end{array}$} & Given position & 0.045 & -0.014 & 0.155 & -0.002 & 0.595 & 0.029 & -0.016 \\
\hline & & Feeling attachment to Company A & 0.056 & 0.317 & 0.039 & 0.079 & 0.613 & -0.077 & -0.079 \\
\hline & & Stable work in a company & 0.007 & 0.216 & -0.131 & 0.008 & 0.759 & 0.038 & -0.138 \\
\hline & & Work in a highly visible company & 0.006 & 0.028 & -0.050 & -0.083 & 0.665 & 0.034 & 0.035 \\
\hline & \multirow{10}{*}{ Ability } & $\begin{array}{l}\text { Ability based on building a smooth } \\
\text { relationship with customers }\end{array}$ & 0.528 & 0.111 & 0.075 & 0.018 & -0.173 & 0.026 & -0.213 \\
\hline & & $\begin{array}{l}\text { Ability based on discovering needs by } \\
\text { analysing information }\end{array}$ & 0.738 & -0.076 & 0.089 & -0.027 & -0.193 & 0.055 & 0.043 \\
\hline & & $\begin{array}{l}\text { Ability based on recommendation to help } \\
\text { customers solve troubles }\end{array}$ & 0.780 & -0.025 & -0.091 & -0.103 & 0.066 & 0.106 & 0.032 \\
\hline & & Ability based on creating actions of interest & 0.710 & 0.041 & -0.006 & 0.020 & 0.103 & -0.042 & 0.031 \\
\hline & & Ability based on handling data & 0.721 & -0.234 & 0.080 & -0.058 & 0.153 & -0.050 & 0.180 \\
\hline & & Ability based on logical analysis & 0.682 & -0.209 & 0.105 & -0.086 & 0.133 & 0.057 & 0.155 \\
\hline & & Ability based on actions to fit policy & 0.470 & 0.032 & -0.158 & 0.118 & 0.337 & 0.143 & 0.007 \\
\hline & & Ability based on sales & 0.783 & -0.036 & -0.098 & 0.006 & 0.089 & 0.047 & 0.013 \\
\hline & & $\begin{array}{l}\text { Ability based on communication with } \\
\text { customers }\end{array}$ & 0.707 & 0.193 & 0.011 & -0.011 & -0.182 & -0.161 & 0.040 \\
\hline & & $\begin{array}{l}\text { Ability based on complying with } \\
\text { customers' requests }\end{array}$ & 0.653 & 0.054 & 0.102 & 0.062 & -0.058 & -0.152 & -0.163 \\
\hline & Knowledge & $\begin{array}{l}\text { Knowledge of Company A's products and } \\
\text { services }\end{array}$ & 0.485 & 0.126 & -0.099 & 0.021 & 0.021 & -0.058 & -0.173 \\
\hline \multirow[b]{2}{*}{ Attributes } & & Number of preschool children & -0.119 & 0.024 & 0.058 & 0.036 & 0.050 & -0.078 & 0.516 \\
\hline & & $\begin{array}{l}\text { Number of elementary and junior high } \\
\text { school students }\end{array}$ & 0.017 & 0.077 & 0.066 & 0.060 & -0.297 & 0.146 & 0.478 \\
\hline
\end{tabular}

Next, extracted seven factor structures were interpreted and their names were investigated. The first factor was named as "the ability to effectively recommend products and services based on customers' needs" because this is constructed through variables that relate to abilities that understand customers' needs, sense of values, and knowledge. The second factor was named as "motivation from brand loyalty" because it is constructed using variables related to "brand loyalty" and "motivation". The third factor is named and constructed only 
with variables related to "realising feelings and satisfaction by using Company A's products and services". The fourth factor was named as "motivation to learn housekeeping techniques" because it is constructed with many variables related to learning about housekeeping in life awareness. The fifth factor was named and constructed regarding the "sense of job and motivation in company A". The sixth factor was named as "taste into home and going out" because it is constructed regarding self-evaluation even in life awareness, importance, and their sense of consumption values. The seventh factor was constructed using childcare time and the number of preschool children, primary and junior high school students andwas named as "time pressure by childcare".

Next, service providers were classified into types by Ward's clustering method, based on their factor scores.

Table 10

Factor's Name (Questionnaire by Service Providers)

1st Factor (Contribution Rate 20.60\%)

\begin{tabular}{lll}
\hline \multicolumn{2}{c}{ 1st factor } & \\
\hline The ability to effectively recommend products and service based on customers' needs & Factor loadings \\
\hline Ability based on building a smooth relationship with customers & Ability & 0.528 \\
Ability based on discovering needs with analysing information & Ability & 0.738 \\
Ability based on recommendation to help customers solve troubles & Ability \\
Ability based on creating actions of interested & Ability & 0.780 \\
Ability based on handling data & Ability & 0.710 \\
Ability based on logical analysis & Ability & 0.721 \\
Ability based on actions to fit policy & Ability & 0.682 \\
Ability based on sales & Ability & 0.470 \\
Ability based on communication with customers' requests & Ability & 0.783 \\
Ability based on complying with requests of customers & Ability & 0.707 \\
Knowledges of Company A' products and services & Knowledge & 0.653 \\
\hline
\end{tabular}

2nd Factor (Contribution Rate 10.40\%)

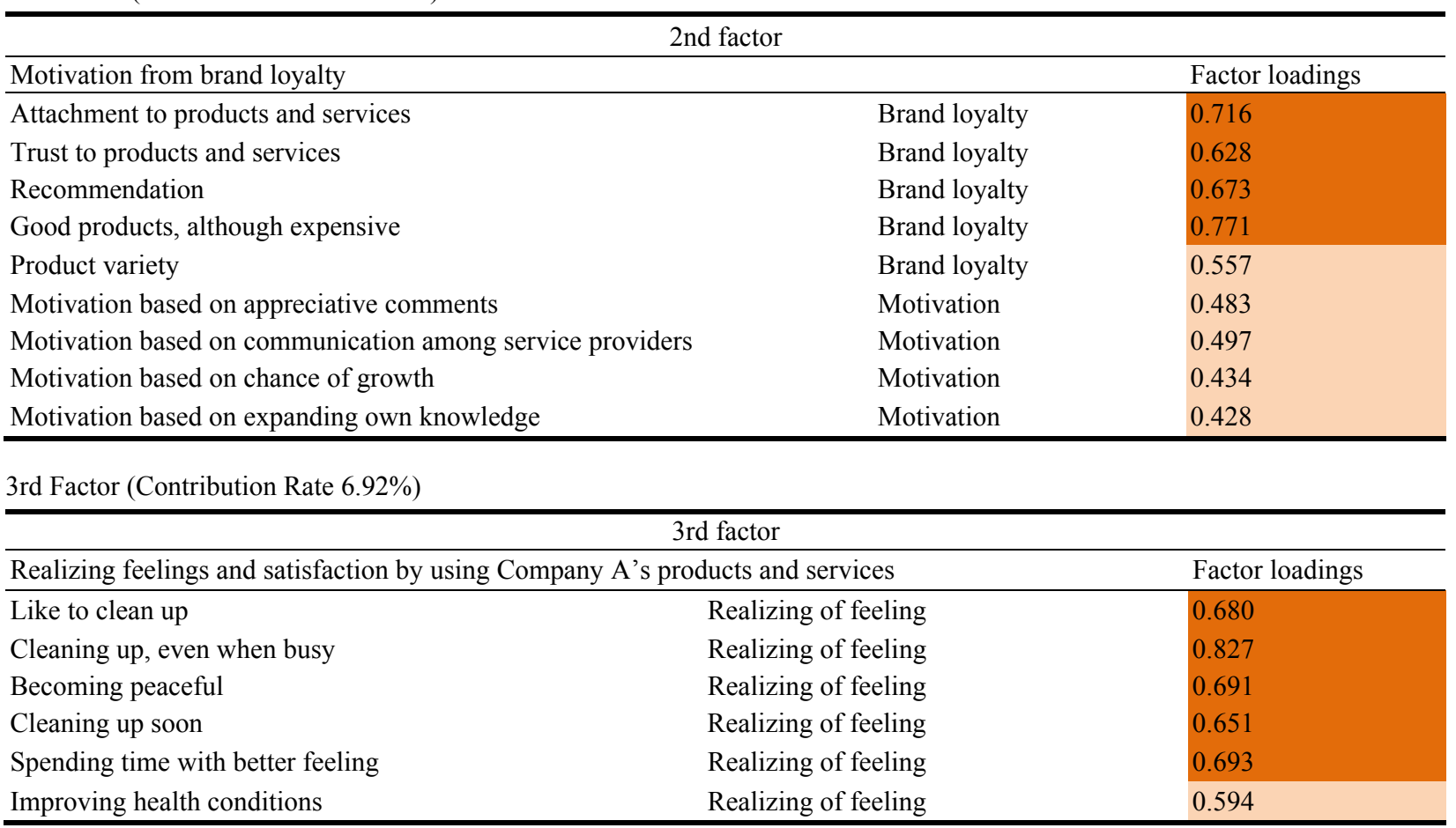


4th Factor (Contribution Rate 5.52\%)

\begin{tabular}{lll}
\hline & 4th factor & Factor loadings \\
\hline Motivation to learn housekeeping techniques & & 0.825 \\
Knowledge of cooking techniques & Life awareness & 0.794 \\
Knowledge of washing techniques & Life awareness & 0.817 \\
Knowledge of cleaning techniques & Life awareness & 0.741 \\
Knowledge of shopping techniques & Life awareness & 0.556 \\
\hline
\end{tabular}

5th Factor (Contribution Rate 20.6\%)

\begin{tabular}{lll}
\hline & 5th factor & Factor loadings \\
\hline Sense of job and motivation in Company A & & 0.595 \\
\hline Given position & A sense of job in Company A & 0.613 \\
Feeling attachment to Company A & A sense of job in Company A & 0.759 \\
Stable work in a company & A sense of job in Company A & 0.665 \\
Work in a highly visible company & A sense of job in Company A & \\
\hline
\end{tabular}

6th Factor (Contribution Rate 20.6\%)

\begin{tabular}{lll}
\hline & 6th factor & Factor loadings \\
\hline Taste into home and going out & & 0.453 \\
Self-evaluation & Life awareness & 0.57 \\
Fashion and jewelry goods & Importance in life & 0.543 \\
Cosmetic items for women & Importance in life & 0.6 \\
Interior & Importance in life & 0.563 \\
Focus on quality of products and services & Sense of consumption value & 0.457 \\
Focus on convenience & Sense of consumption value & 0.589 \\
Focus on lifestyle & Sense of consumption value & \\
\hline
\end{tabular}

7th Factor (Contribution Rate 20.6\%)

\begin{tabular}{lll}
\hline & 7th factor & Factor loadings \\
\hline Time pressure by child care & & 1.05 \\
\hline Time of raising children & Lifestyle & 0.516 \\
Number of preschool children & Attributes & 0.478 \\
Number of elementary and junior high school students & Attributes & \\
\hline
\end{tabular}

Table 11 shows the number and their average of factor scores of each type, on the case of 3-5 cluster members, and their clusters are compared and the number of type is determined.

Table 11

The Result of Clustering of Service Providers (the Number of Clusters 3-5)

3 Clusters

\begin{tabular}{llll}
\hline 3 Clusters & Group 1 & Group 2 & Group 3 \\
\hline 1st factor & 0.558 & -0.580 & -0.244 \\
2nd factor & 0.639 & -0.688 & -0.229 \\
3rd factor & 0.356 & -0.538 & 0.201 \\
4th factor & 0.033 & -0.264 & 0.474 \\
5th factor & 0.285 & -0.497 & 0.302 \\
6th factor & 0.263 & -0.424 & 0.205 \\
7th factor & -0.597 & -0.193 & 1.994 \\
Number of people & 61 & 49 & 23 \\
\hline
\end{tabular}


4 Clusters

\begin{tabular}{lllll}
\hline 4 Clusters & Group 1 & Group 2 & Group 3 & Group 4 \\
\hline 1st factor & 0.551 & 0.564 & -0.580 & -0.244 \\
2nd factor & 0.776 & 0.506 & -0.688 & -0.229 \\
3rd factor & 0.045 & 0.657 & -0.538 & 0.201 \\
4th factor & -0.597 & 0.642 & -0.264 & 0.474 \\
5th factor & -0.030 & 0.591 & -0.497 & 0.302 \\
6th factor & -0.158 & 0.670 & -0.424 & 0.205 \\
7th factor & -0.710 & -0.488 & -0.193 & 1.994 \\
Number of people & 30 & 31 & 49 & 23 \\
\hline
\end{tabular}

5 Clusters

\begin{tabular}{llllll}
\hline 5 Clusters & Group 1 & Group 2 & Group 3 & Group 4 & Group 5 \\
\hline 1st factor & 0.551 & 0.564 & -0.572 & -0.598 & -0.244 \\
2nd factor & 0.776 & 0.506 & -0.678 & -0.709 & -0.229 \\
3rd factor & 0.045 & 0.657 & -0.632 & -0.325 & 0.201 \\
4th factor & -0.597 & 0.642 & -0.556 & 0.399 & 0.474 \\
5th factor & -0.030 & 0.591 & -0.176 & -1.223 & 0.302 \\
6th factor & -0.158 & 0.670 & -0.843 & 0.527 & 0.205 \\
7th factor & -0.710 & -0.488 & -0.268 & -0.021 & 1.994 \\
Number of people & 30 & 31 & 34 & 15 & 23 \\
\hline
\end{tabular}

Table 12

Service Providers' Characteristic Based on Each Number of Cluster

3 Clusters

\begin{tabular}{llll}
\hline & Type 1 & Type 2 & Type 3 \\
\hline 1st factor & High & Low & Middle \\
2nd factor & High & Low & Middle \\
3rd factor & Middle & Low & Middle \\
4th factor & Middle & Middle & Middle-high \\
5 th factor & Middle-high & Middle & Middle \\
6th factor & Middle & Low-middle & Middle \\
7th factor & Low & Middle & High \\
\hline
\end{tabular}

4 Clusters

\begin{tabular}{lllll}
\hline & Type 1 & Type 2 & Type 3 & Type 4 \\
\hline 1st factor & High & High & Low & Middle \\
2nd factor & High & Middle-high & Low & Middle \\
3rd factor & Middle & High & Low & Middle \\
4th factor & Low & Middle-high & Middle & Middle-high \\
5 th factor & Middle & High & Middle & Middle \\
6th factor & Middle & High & Low-middle & Middle \\
7th factor & Low & Low-middle & Middle & High \\
\hline
\end{tabular}

\section{Clusters}

\begin{tabular}{llllll}
\hline & Type 1 & Type 2 & Type 3 & Type 4 & Type 5 \\
\hline 1st factor & High & High & Low & Low & Middle \\
2nd factor & High & Middle-high & Low & Low & Middle \\
3rd factor & Middle & High & Low & Middle & Middle \\
4th factor & Low & Middle-high & Low & Middle & Middle-high \\
\hline
\end{tabular}


(Table 12 continued)

\begin{tabular}{llllll}
\hline 5th factor & Middle & High & Middle & Low & Middle \\
6th factor & Middle & High & Low & High & Middle \\
7th factor & Low & Low-middle & Middle & Middle & High \\
\hline
\end{tabular}

From Table 11, type 1 of cluster 3 is divided into types 1 and 2 of cluster 4.

From Table 12, their characteristics are compared, 2nd-7th factors are evaluated differently, and it is appropriate to divide them into four clusters. In addition, type 3 of four clusters is divided into clusters 3 and 4 of five clusters. However, it is few that group 4 has only 15 people, and then the analysis could not be continued. Therefore, the number of clusters is adapted as four. Table 13 shows detailed characteristics in the case of four clusters. Table 14 shows characteristics by comprehensive evaluation in the case of four clusters.

Table 13

Detailed Characteristics in the Case of 4 Clusters

\begin{tabular}{|c|c|c|c|c|c|c|c|c|c|c|}
\hline Type & Factor & $\begin{array}{l}\text { Average } \\
\text { of factor } \\
\text { scores }\end{array}$ & $\begin{array}{l}\text { Evaluation } \\
\text { of average }\end{array}$ & $\begin{array}{l}\text { Median of } \\
\text { factor } \\
\text { scores }\end{array}$ & $\begin{array}{l}\text { Evaluation } \\
\text { of median }\end{array}$ & $\begin{array}{l}\text { Percentage } \\
\text { of people: } \\
\sim-0.5 \text { (low) }\end{array}$ & $\begin{array}{l}\text { Percentage } \\
\text { of people: } \\
-0.5 \sim 0.5 \\
\text { (middle) }\end{array}$ & $\begin{array}{l}\text { Percentage } \\
\text { of people: } \\
0.5 \sim \text { (high) }\end{array}$ & $\begin{array}{l}\text { Evaluation } \\
\text { from } \\
\text { percentage } \\
\text { of people }\end{array}$ & $\begin{array}{l}\text { Total } \\
\text { evaluation }\end{array}$ \\
\hline \multirow{7}{*}{$\begin{array}{l}\text { Type } \\
\text { A }\end{array}$} & 1 st factor & 0.551 & High & 0.551 & High & 10.0 & 33.3 & 56.7 & High & High \\
\hline & 2nd factor & 0.776 & High & 0.776 & High & 0.0 & 36.7 & 63.3 & High & High \\
\hline & 3rd factor & 0.045 & Hiddle & 0.045 & Middle & 23.3 & 50.0 & 26.7 & Middle & Middle \\
\hline & 4 th factor & -0.597 & Low & -0.597 & Low & 56.7 & 43.3 & 0.0 & Low & Low \\
\hline & 5 th factor & -0.030 & Middle & -0.030 & Middle & 23.3 & 53.3 & 23.3 & Middle & Middle \\
\hline & 6th factor & -0.158 & Middle & -0.158 & Middle & 26.7 & 60.0 & 13.3 & Middle & Middle \\
\hline & 7 th factor & -0.710 & Low & -0.710 & Low & 73.3 & 26.7 & 0.0 & Low & Low \\
\hline \multirow{7}{*}{$\begin{array}{l}\text { Type } \\
\text { B }\end{array}$} & 1st factor & 0.564 & High & 0.564 & High & 16.1 & 29.0 & 54.8 & High & High \\
\hline & 2nd factor & 0.506 & High & 0.506 & High & 0.0 & 54.8 & 45.2 & Middle & $\begin{array}{l}\text { Middle- } \\
\text { high }\end{array}$ \\
\hline & 3rd factor & 0.657 & High & 0.657 & High & 0.0 & 41.9 & 58.1 & High & High \\
\hline & 4th factor & 0.642 & High & 0.642 & High & 3.2 & 48.4 & 48.4 & Middle & $\begin{array}{l}\text { Middle- } \\
\text { high }\end{array}$ \\
\hline & 5 th factor & 0.591 & High & 0.591 & High & 0.0 & 32.3 & 67.7 & High & High \\
\hline & 6 th factor & 0.670 & High & 0.670 & High & 0.0 & 32.3 & 67.7 & High & High \\
\hline & 7 th factor & -0.488 & Middle & -0.488 & Middle & 51.6 & 45.2 & 3.2 & Low & $\begin{array}{l}\text { Low- } \\
\text { middle }\end{array}$ \\
\hline \multirow{7}{*}{$\begin{array}{l}\text { Type } \\
\text { C }\end{array}$} & 1st factor & -0.580 & Low & -0.580 & Low & 61.2 & 36.7 & 2.0 & Low & Low \\
\hline & 2nd factor & -0.688 & Low & -0.688 & Low & 57.1 & 34.7 & 8.2 & Low & Low \\
\hline & 3rd factor & -0.538 & Low & -0.538 & Low & 46.9 & 46.9 & 6.1 & Low & Low \\
\hline & 4th factor & -0.264 & Middle & -0.264 & Middle & 36.7 & 44.9 & 18.4 & Middle & Middle \\
\hline & 5 th factor & -0.497 & Middle & -0.497 & Middle & 36.7 & 51.0 & 12.2 & Middle & Middle \\
\hline & 6th factor & -0.424 & Middle & -0.424 & Middle & 51.0 & 28.6 & 20.4 & Low & $\begin{array}{l}\text { Low- } \\
\text { middle }\end{array}$ \\
\hline & 7 th factor & -0.193 & Middle & -0.193 & Middle & 22.4 & 67.3 & 10.2 & Middle & Middle \\
\hline \multirow{7}{*}{$\begin{array}{l}\text { Type } \\
\text { D }\end{array}$} & 1st factor & -0.244 & Middle & -0.244 & Middle & 34.8 & 39.1 & 26.1 & Middle & Middle \\
\hline & 2nd factor & -0.229 & Middle & -0.229 & Middle & 34.8 & 47.8 & 17.4 & Middle & Middle \\
\hline & 3rd factor & 0.201 & Middle & 0.201 & Middle & 13.0 & 60.9 & 26.1 & Middle & Middle \\
\hline & 4th factor & 0.474 & Middle & 0.474 & Middle & 13.0 & 30.4 & 56.5 & High & $\begin{array}{l}\text { Middle- } \\
\text { high }\end{array}$ \\
\hline & 5 th factor & 0.302 & Middle & 0.302 & Middle & 13.0 & 52.2 & 34.8 & Middle & Middle \\
\hline & 6 th factor & 0.205 & Middle & 0.205 & Middle & 17.4 & 43.5 & 39.1 & Middle & Middle \\
\hline & 7 th factor & 1.994 & High & 1.994 & High & 0.0 & 0.0 & 100.0 & High & High \\
\hline
\end{tabular}


Table 14

Characteristics of Service Provider Types by Comprehensive Evaluation

\begin{tabular}{|c|c|c|c|c|c|c|}
\hline 4 Clusters & Factor's name & $\begin{array}{l}\text { Contribution } \\
\text { rate }\end{array}$ & Type A & Type B & Type C & Type D \\
\hline 1st factor & $\begin{array}{l}\text { The ability to effectively recommend Products } \\
\text { and service based on customers' needs }\end{array}$ & $20.60 \%$ & High & High & Low & Middle \\
\hline 2nd factor & Motivation from brand loyalty & $10.40 \%$ & High & $\begin{array}{l}\text { Middle- } \\
\text { High }\end{array}$ & Low & Middle \\
\hline 3rd factor & $\begin{array}{l}\text { Realizing feelings and satisfaction by using } \\
\text { company a's products and services }\end{array}$ & $6.92 \%$ & Middle & High & Low & Middle \\
\hline 4th factor & Motivation to learn housekeeping techniques & $5.52 \%$ & Low & High & Middle & $\begin{array}{l}\text { Middle- } \\
\text { high }\end{array}$ \\
\hline 5 th factor & Sense of job and motivation in Company A & $5.13 \%$ & Middle & High & Middle & Middle \\
\hline 6th factor & Taste into home and going out & $4.70 \%$ & Middle & High & $\begin{array}{l}\text { Low- } \\
\text { middle }\end{array}$ & Middle \\
\hline 7th factor & Time pressure by childcare & $3.84 \%$ & Low & $\begin{array}{l}\text { Low- } \\
\text { middle }\end{array}$ & Middle & High \\
\hline \multicolumn{3}{|c|}{ Number of people } & 30 & 31 & 49 & 23 \\
\hline
\end{tabular}

\begin{tabular}{|c|c|c|c|c|c|}
\hline \multirow{6}{*}{ Age } & $20 \mathrm{~s}$ & 0 & 1 & 0 & 1 \\
\hline & $30 \mathrm{~s}$ & 1 & 1 & 4 & 10 \\
\hline & $40 \mathrm{~s}$ & 4 & 12 & 18 & 7 \\
\hline & $50 \mathrm{~s}$ & 16 & 13 & 20 & 4 \\
\hline & $60 \mathrm{~s}$ & 7 & 4 & 4 & 0 \\
\hline & 70 s and over & 2 & 0 & 3 & 1 \\
\hline \multirow{6}{*}{$\begin{array}{l}\text { Condition of } \\
\text { youngest child }\end{array}$} & presschool children & 0 & 0 & 2 & 9 \\
\hline & \begin{tabular}{|l} 
elementary or junior \\
high shool students
\end{tabular} & 3 & 9 & 13 & 13 \\
\hline & \begin{tabular}{|l}
$\begin{array}{l}\text { high shool or } \\
\text { university students }\end{array}$ \\
\end{tabular} & 3 & 4 & 10 & 0 \\
\hline & working people & 16 & 12 & 18 & 0 \\
\hline & \begin{tabular}{|l|} 
have youngest children \\
without living together
\end{tabular} & 6 & 3 & 6 & 0 \\
\hline & no children & 2 & 3 & 0 & 1 \\
\hline \multirow{6}{*}{$\begin{array}{l}\text { Average of } \\
\text { childcare } \\
\text { duration/day }\end{array}$} & no childkare time & 27 & 22 & 34 & 0 \\
\hline & under 1 hour & 2 & 3 & 5 & 0 \\
\hline & $1-3$ hours & 1 & 6 & 10 & 6 \\
\hline & $3-5$ hours & 0 & 0 & 0 & 4 \\
\hline & $5 \sim 7$ hours & 0 & 0 & $\mathbf{0}$ & 6 \\
\hline & 7 hours and over & 0 & 0 & 0 & 7 \\
\hline \multirow{6}{*}{$\begin{array}{l}\text { Usage period of } \\
\text { products or } \\
\text { services }\end{array}$} & under 1 year & 0 & 0 & 2 & 7 \\
\hline & $1 \sim 4$ years & 0 & 4 & 6 & 7 \\
\hline & $4-7$ years & 2 & 2 & 6 & 3 \\
\hline & $7-10$ years & 3 & 7 & 4 & 2 \\
\hline & $10-20$ years & 13 & 7 & 19 & 4 \\
\hline & 20 years and over & 12 & 11 & 12 & 0 \\
\hline
\end{tabular}

Figure 4. Histograms of attributes on each type.

Figure 4 illustrates the histograms regarding attributes (age, condition of youngest child, childcare duration, and usage period of products or service) of each service provider.

Table 15 reveals the interpretations of each service provider's type, based on Table 14 and Figure 4. 
Table 15

Interpretation of Each Type

\begin{tabular}{ll}
\hline Type & Interpretation \\
Type A & $\begin{array}{l}\text { This type has high confidence in products and services. Therefore, they have a high ability to recommend products } \\
\text { and services, but low "motivation to learn housekeeping knowledge and techniques" and "time pressure by } \\
\text { childcare". Their age mode is in the 50s. }\end{array}$ \\
\hline & $\begin{array}{l}\text { This type is highly "concerned with home and going out", which is why they use Company A's products and } \\
\text { services. Realizing feelings that "motivate learning housekeeping knowledge and techniques", a strong sense of job } \\
\text { value and motivation, and an increasing "trust in products and services" and high "abilities to promote products and } \\
\text { services based on customers' needs". Their age mode is in the 40s and 50s. }\end{array}$ \\
& $\begin{array}{l}\text { This type has a low "concern with home and going out". Although they use Company A's products and services, this } \\
\text { does not change their "motivation to learn housekeeping knowledge and techniques" or a sense of job values and } \\
\text { motivation. Therefore, they have low confidence in products and services, as well as low "abilities to promote products } \\
\text { and service based on customers' needs". Their children are relatively grown and their age mode is in the 40s-50s. }\end{array}$ \\
\hline Type D & $\begin{array}{l}\text { This type has fairly high "motivation to learn housekeeping knowledge and techniques", they grow children well, and } \\
\text { are younger service providers with an age mode in the 30s. }\end{array}$ \\
\hline
\end{tabular}

If the averages of purchases are focused on, Table 14 and Figure 5 show that amount of customer's purchases depends on service providers' abilities and a sense of values except for type D who are working on childcare. That is, the highest one is type B, in which both service providers' abilities and motivation are high, and the lowest one is type $\mathrm{C}$, in which both service providers' abilities and motivation are low.

Most of service providers of type D are working on childcare and their average is low even though their motivation and skills are not so low.

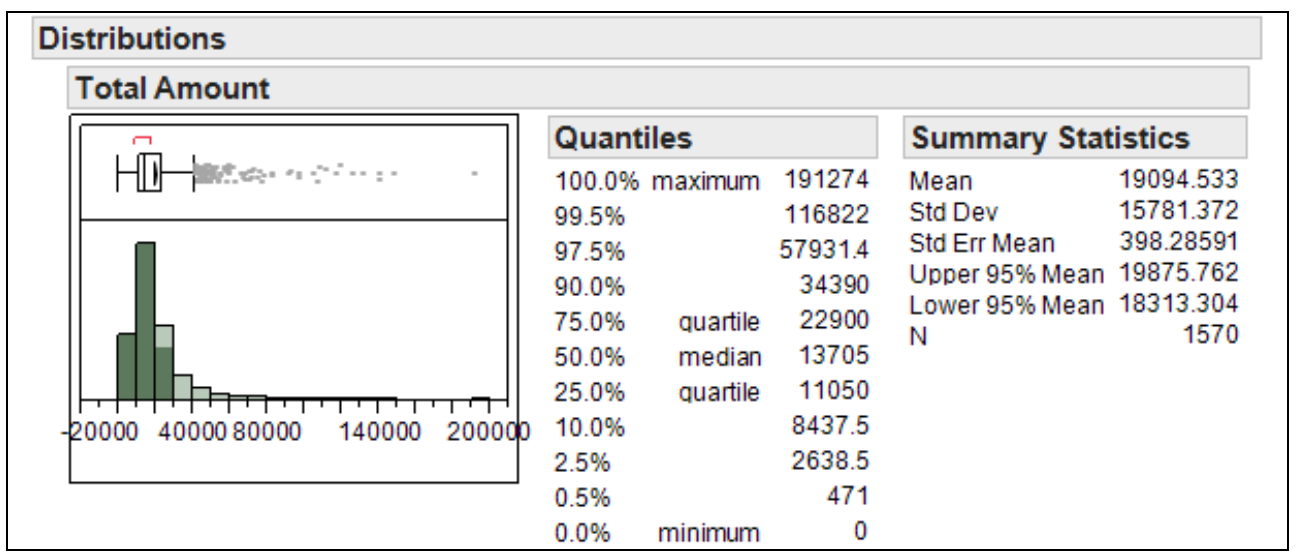

(a) Type A

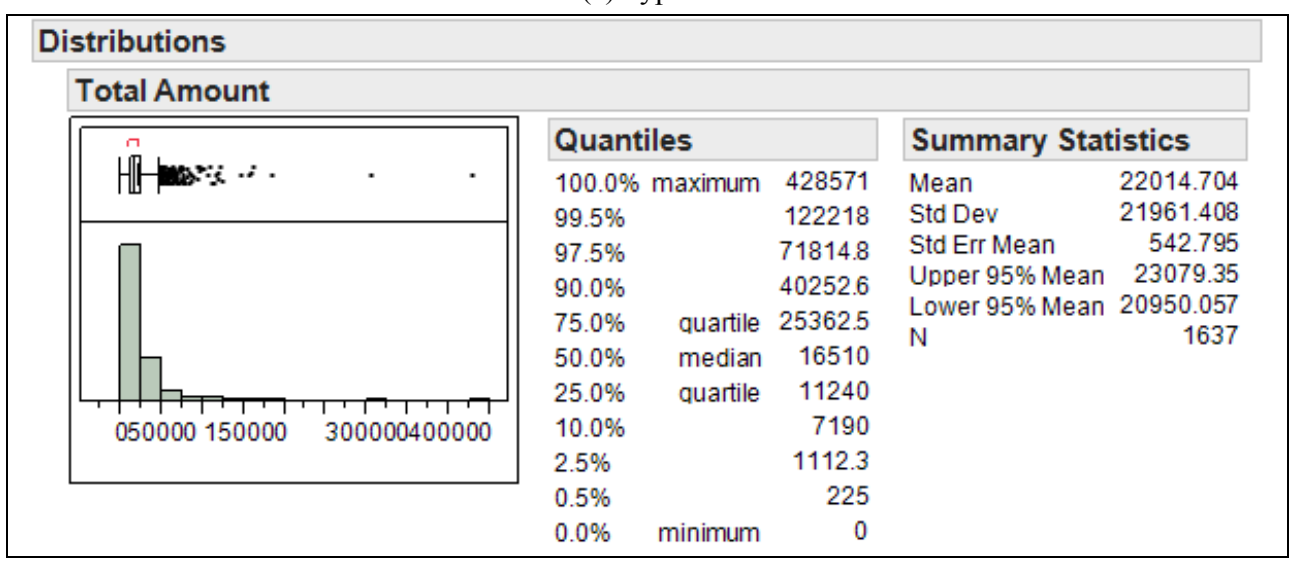

(b) Type B 


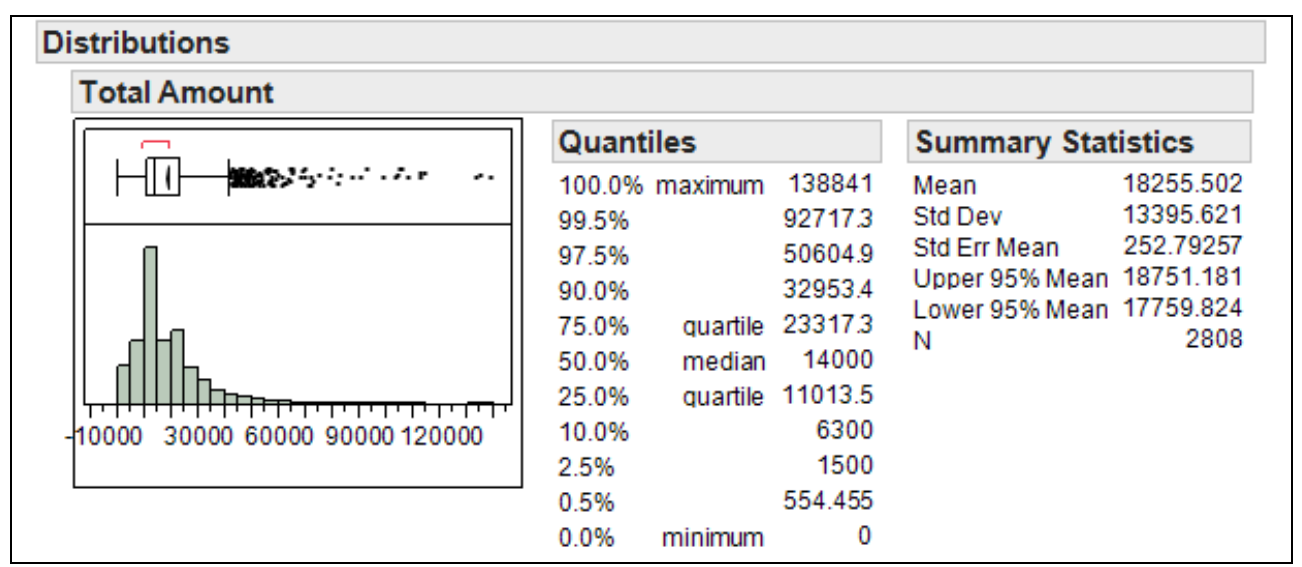

(c) Type C

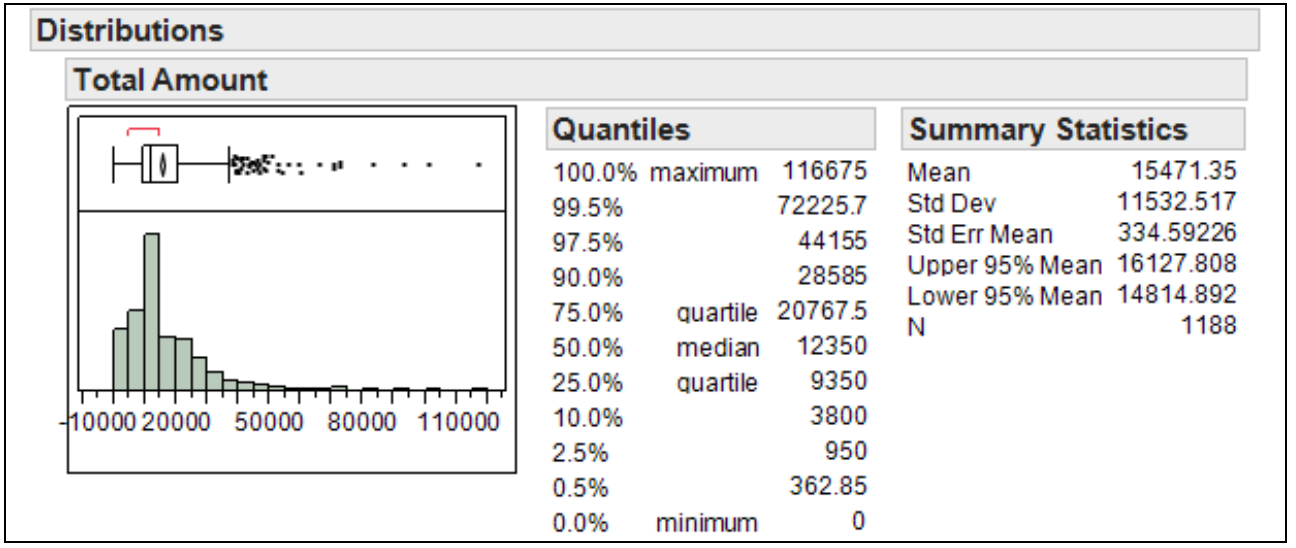

(d) Type D

Figure 5. Histograms regarding sales by each service provider type and fundamental statistics.

\section{Comparison and Investigation of the Structure of Bayesian Network for Each Combination Between}

\section{Customer Types and Service Provider Types}

Construction and discussion of each purchase Bayesian network model for each combination between customer types and service provider types. In this chapter, a purchasing Bayesian Network for each combination between customer and service provider types is constructed, extracted in previous chapters. Customers corresponding to service provider types are analysed, and have been typed by customer types (Figure 6).

\begin{tabular}{|c|c|c|c|c|c|c|}
\hline service provider type & Type1 & Type2 & Type3 & Type4 & Type5 & Type6 \\
\hline TypeA & & & & & & \\
\hline TypeB & & & & & & \\
\hline TypeC & & & & & & \\
\hline TypeD & & & & & & \\
\hline
\end{tabular}

Figure 6. Combination between service provider and customer types.

As the data could not be analysed if no questionnaire survey response was provided for both service providers and corresponding customers, questionnaire survey data are analysed for 117 service providers with more than one customer-answered questionnaire survey, or 2,898 customers' survey data and their purchase history. A hypothesis is constructed in these Bayesian networks to narrow questionnaire survey variables to 
those in product categories, to analyse how customers' sense of values, needs, and demands influence categories of purchase products. All variables were changed to variables with the below two values.

Transformation to the product categories' binary variable: Transform to "yes" when they purchase from the product categories, and "no" if they did not purchase.

Transformation to the questionnaire's binary variable: Transform levels 1, 2, and 3 to "low", and 4 and 5 to "high"; exceptions are as follows.

Transformation to the questionnaire's binary variable (exception);

Transformation to the childcare binary variable: Transform if not raising a child to "no", or to "yes" if raising a child.

Transformation to the binary variable of junior high school students: Transform 0 children as "no", or one child or more to "yes".

Additionally, Bayesian Network models were constructed using BAYONET, a Bayesian network-constructing support system. The probability structure research was conducted using AIC criteria by Greedy search.

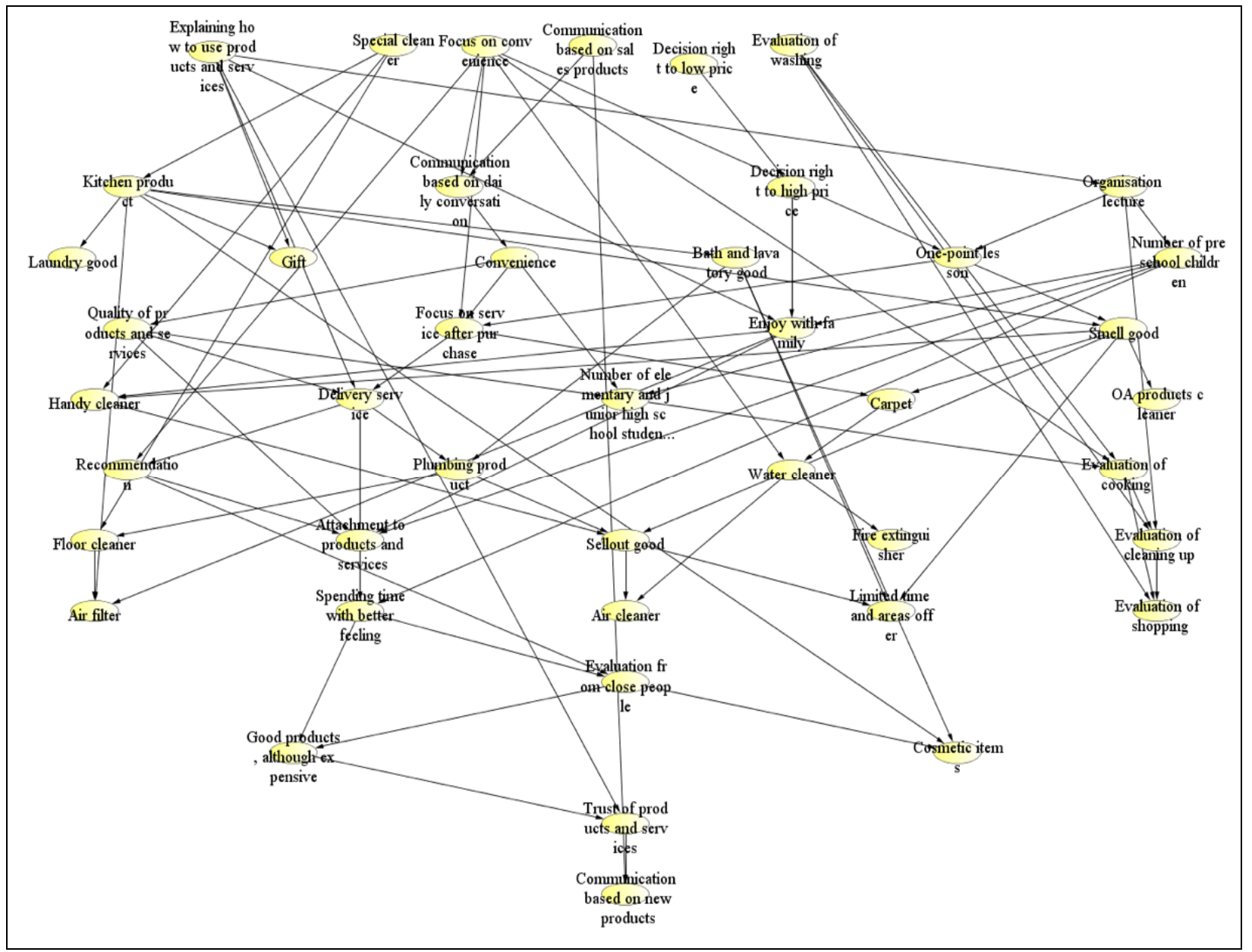

Figure 7. Purchasing Bayesian network model spD/cu3.

Figure 7 illustrates an example of a purchasing Bayesian network with a combination of service provider type $\mathrm{D}$ and customer type 3 , noted as "spD/cu3" below. 
The connection between customers' sense of values, needs, and preferences and their purchase behaviours is examined in Figure 7. The "Explaining how to use products and services" node connects to the "lecture of organisation", "delightfully clean up with family", "delivery service", "trust products and services", and "gift" nodes. This demonstrates that the "how to use products and services" node is a parent node of the five children nodes. Therefore, the "Explaining how to use products and services" parent node is key among the nodes. The "hub" concept is introduced in this paper (Imoto, 2011), and refers to a strong variable of influence to the child nodes in each Bayesian network model. Hubs in this study are extremely reduced when they are defined as having more than five child nodes. Similarly, hubs extremely increase when they are defined as having more than three child nodes. Therefore, there is no merit in discussing "hubs" in this instance, as hubs are defined as having more than four child nodes. Table 16 summarises the hubs in each purchasing Bayesian network for the combination of service provider and customer types. Each variable's left digit refers to the number of child nodes in Table 16.

Additionally, the attributes (age, condition of the youngest child, average daily childcare time, and usage period of products or services) and average sales in each combination between service provider and customer types are noted in Figure 8.

Table 16

The Hubs on Each Purchase Bayesian Network

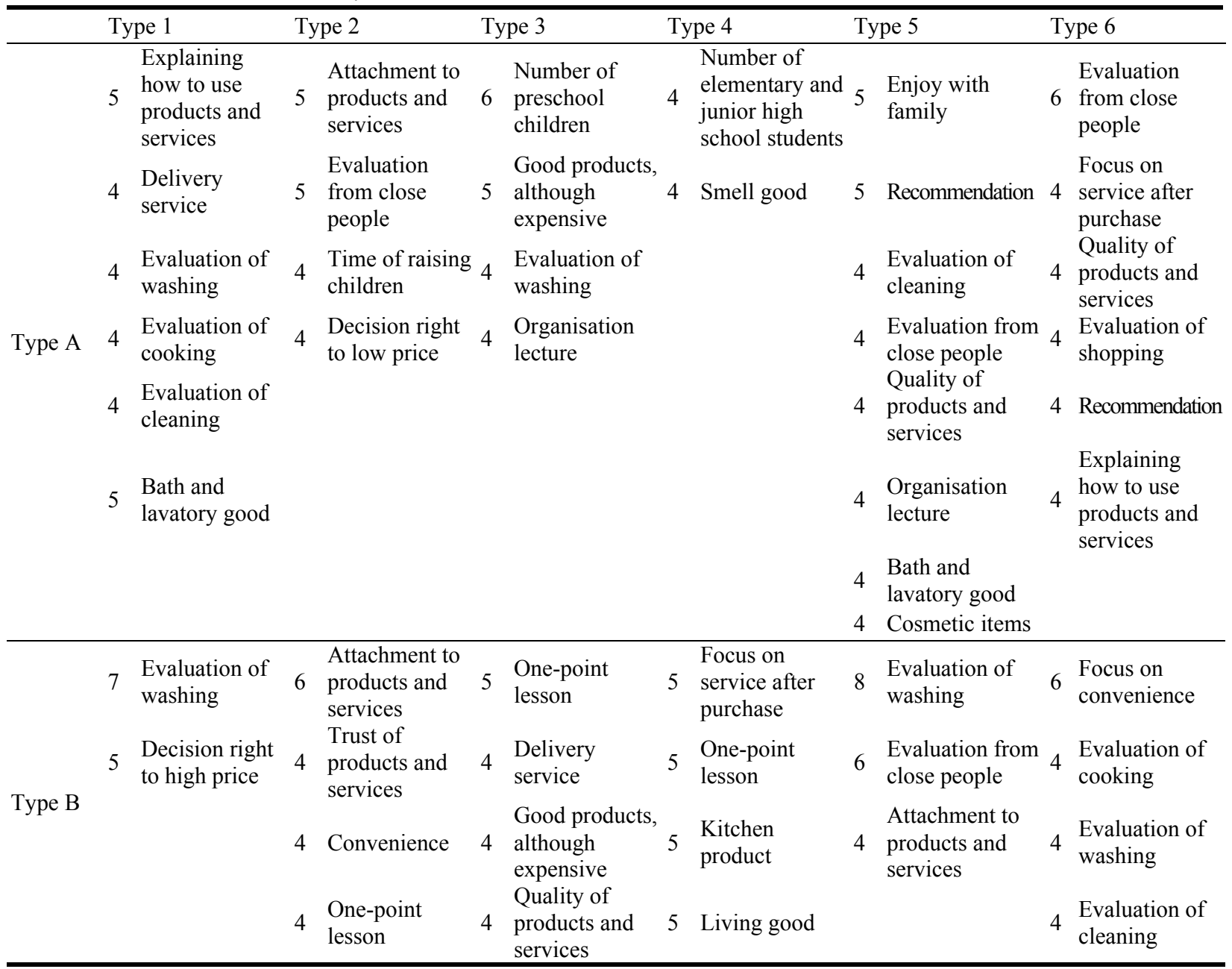


(Table 16 continued)

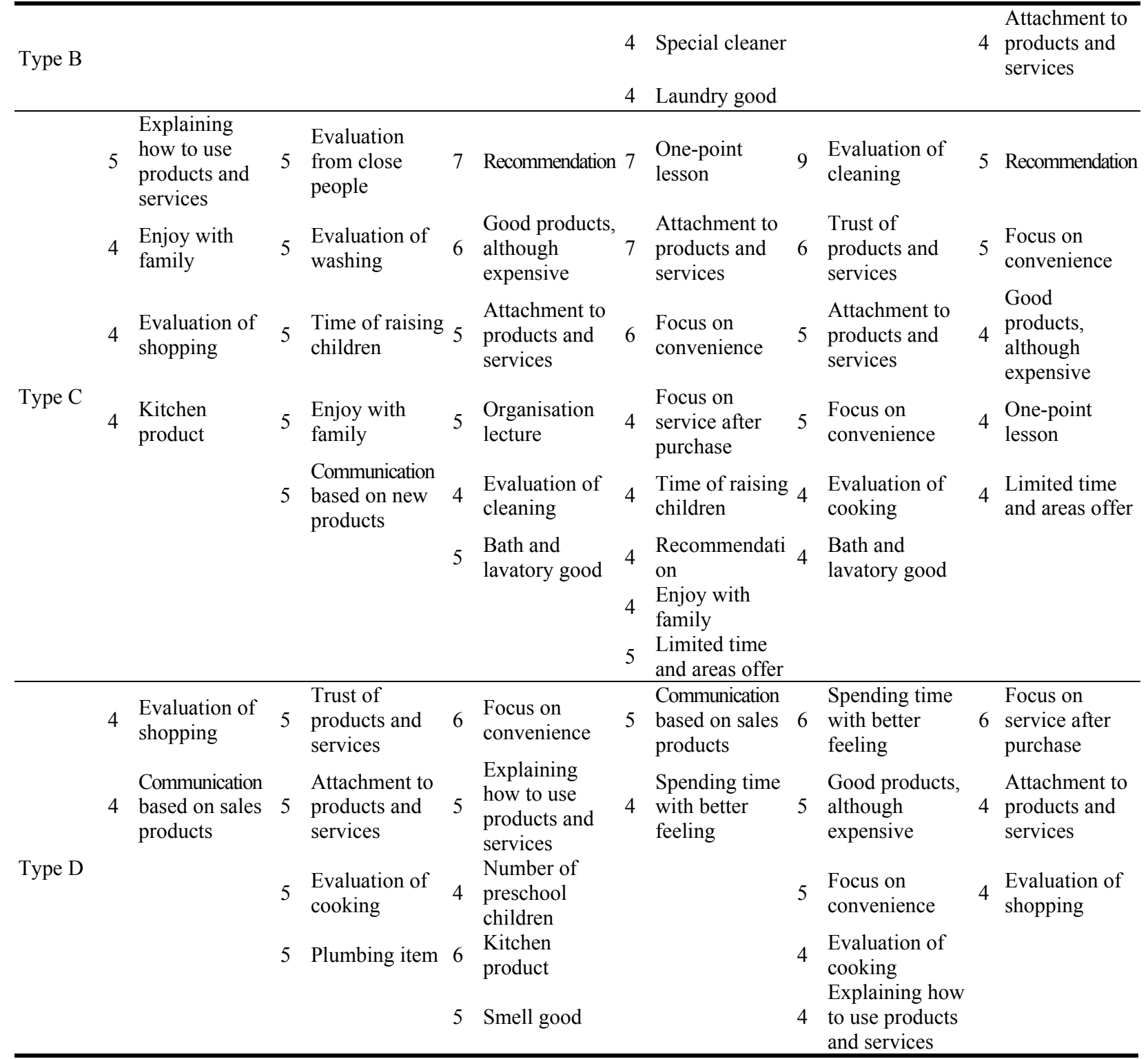




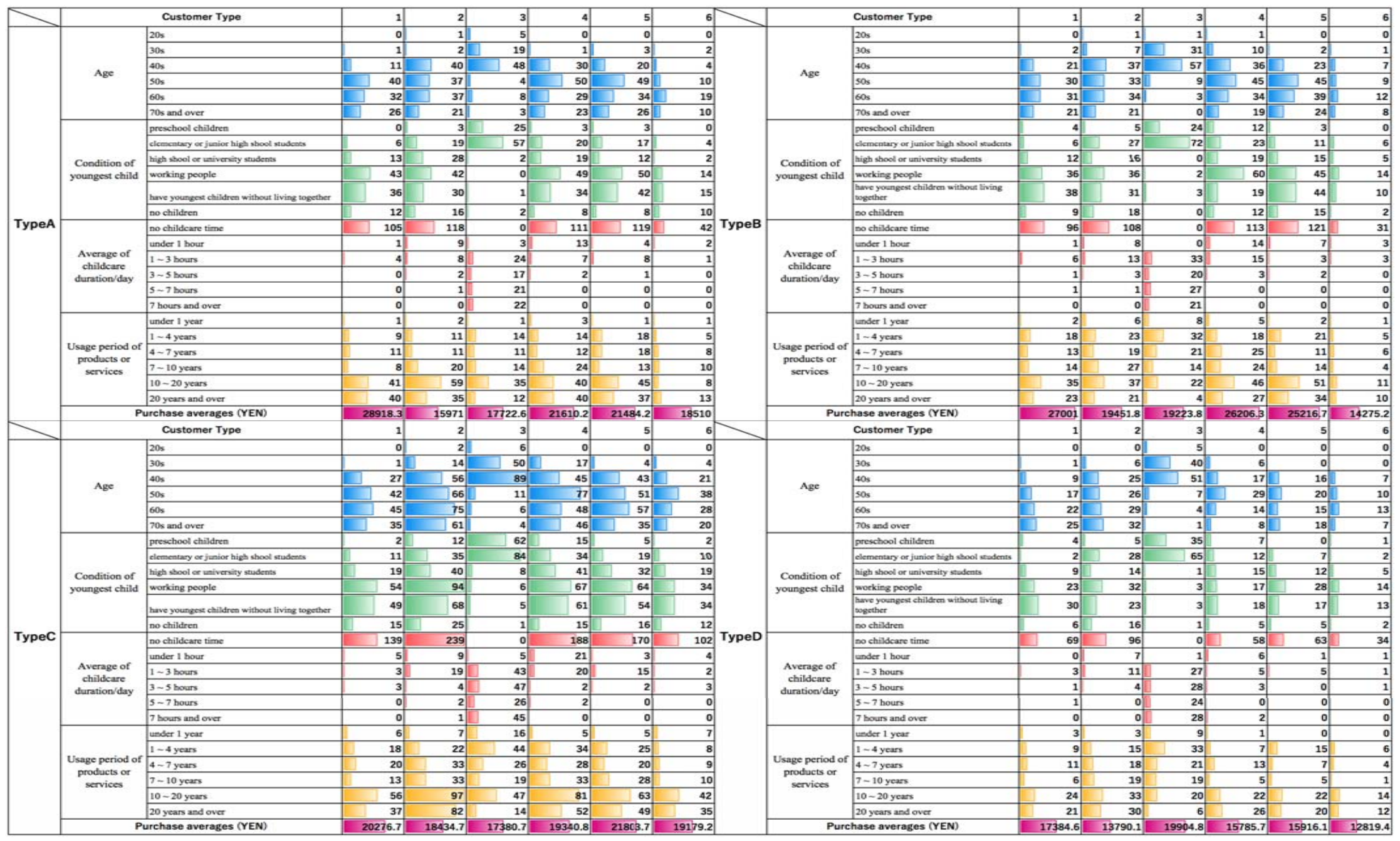

Figure 8. Attribution and average of sales for the combination between each service provider type and customer type. 
Table 16 illustrates that variables with high factor loading scores of the first factor "loyalty caused by realising feelings from using products and services" become hubs in customer types 2, 3, 4, 5, and 6, which are not high loyalty. This means customer loyalty is an important element during purchase behaviour for non-loyal customer types. However, the first factor's variables do not appear as a hub in service provider type A/customer type 4 , and service provider type B/customer type 4 . Further, the first factor of customer type 4 is evaluated as "middle", but the average first factor score for customers corresponding to service provider type A is 0.247 ; the average for service provider type B is 0.211 , and the factor score for customer type 4 is second, followed by customer type 1. Additionally, service provider types A and B exhibit high ability and loyalty. Therefore, the first factor variable does not appear as a hub because the loyalties of combinations between service provider type A/customer type 4, and service provider type B/customer type 4 are relatively high.

Alternatively, the variables with high factor loading scores in the first factor do not appear as hubs in customer type 1 because the loyalty of customer type 1 is already high. However, variables have high factor loading scores for the second factor, "family's evaluation of housework", and fourth factor, "demand for products and services as a housewife".

Further, the average customer purchases of customer type 3, which raises children, tends to depend on the service provider types.

Figure 8 notes that the averages of customer purchases corresponding to service provider types B and D are high in customer type 3 . In service provider type $\mathrm{D}$, the sales averages of all except customer type 3 are lower than other service provider types, but customer type 3's sales average is the highest. As service providers in type D and customers in type 3 raise children, this service provider type understands customers' feelings regarding raising children, and can take an appropriate approach. Additionally, type B service providers have high abilities and motivation; therefore, the purchase averages of customer type 3 as corresponding to service provider types B and D are also high, and service providers in type B can offer customer-oriented service. Moreover, customer type 6 further investigated in Table 6, which notes that these customers do not communicate with their service providers, and their loyalty is evaluated as "low-middle". The sales averages of customers in type 6 as corresponding to service provider types A and C are relatively high. However, one of the customers corresponding to service providers in type $\mathrm{A}$ is an outlier, and demonstrates abnormally high purchasing. The average of customer sales except for the outlier is 16,508 yen. Therefore, the purchase average of customers in customer type 6 corresponding to service providers in type $C$, except the outlier, is the highest. The type $\mathrm{C}$ service providers' abilities and motivation are low, and their self-evaluation is the lowest of all service provider types. Customers in type 6 do not wish to communicate with service providers; therefore, they essentially match service provider type C's sales.

The "kitchen and smell goods" appeared as hubs for service provider type D/customer type 3. According to hearing survey for local service providers in City I, it was found that "kitchen products" include detergents that can wash vegetables and baby bottles. The Bayesian network results were led by an analysis of service providers' sales data. Therefore, the hub analysis of the Bayesian network compels service providers to subconsciously check their own behaviours, and reaffirm and share their knowledge.

Next, combination types are compared. As aforementioned, the hubs of service provider type C/customer type 3 are compared with hubs of service provider type $\mathrm{D} /$ customer type 3 . Service provider type $\mathrm{C}$ has low abilities and confidence in their products and services. Therefore, three variables with high first factor loading appear in these hubs. Additionally, service providers type C's sales average for customer type 3 is the lowest, 
and bath and lavatory goods appear in these hubs. This point is considered as characteristic of service provider type C's sales, because the same situation with service provider type C/customer type 5 is discovered.

Predictions from stochastic reasoning in the Bayesian network for each combination between service provider and customer types. This chapter illustrates the predictions from stochastic reasoning in the Bayesian network for each combination of service provider and customer types. The stochastic reasoning method is used to set the conditions of the customer questionnaire survey ("high" or "low"), and to set product category objective variables ("yes" or "no") and compare the purchase probabilities between the "high" and "low" conditions. Table 17 provides an example of the differences in purchase probability in "high" and "low" conditions.

Table 17

The Differences in Purchase Probability, Conditioned by "High" and "Low"

\begin{tabular}{|c|c|c|c|c|c|c|c|c|c|}
\hline & $\begin{array}{l}\text { Time of } \\
\text { raising } \\
\text { children }\end{array}$ & $\begin{array}{l}\text { Evaluation } \\
\text { of cooking }\end{array}$ & $\begin{array}{l}\text { Evaluation } \\
\text { of washing }\end{array}$ & $\begin{array}{l}\text { Evaluation } \\
\text { of } \\
\text { cleaning } \\
\text { up }\end{array}$ & $\begin{array}{l}\text { Evaluation } \\
\text { of shopping }\end{array}$ & $\begin{array}{l}\text { Spending } \\
\text { time with } \\
\text { better } \\
\text { feeling }\end{array}$ & $\begin{array}{l}\text { Quality of } \\
\text { products } \\
\text { and } \\
\text { services }\end{array}$ & Convenience & $\begin{array}{l}\text { Attachment } \\
\text { to products } \\
\text { and } \\
\text { services }\end{array}$ \\
\hline $\begin{array}{l}\text { OA products } \\
\text { cleaner }\end{array}$ & $0.00 \%$ & $-0.01 \%$ & $0.00 \%$ & $0.00 \%$ & $0.00 \%$ & $-0.02 \%$ & $0.00 \%$ & $0.01 \%$ & $0.01 \%$ \\
\hline Gift & $0.00 \%$ & $-0.01 \%$ & $0.00 \%$ & $0.00 \%$ & $0.00 \%$ & $0.34 \%$ & $0.00 \%$ & $0.00 \%$ & $0.23 \%$ \\
\hline Laundry good & $0.00 \%$ & $0.00 \%$ & $0.00 \%$ & $0.00 \%$ & $0.00 \%$ & $0.00 \%$ & $0.00 \%$ & $0.00 \%$ & $0.00 \%$ \\
\hline Water cleaner & $0.00 \%$ & $-1.09 \%$ & $0.00 \%$ & $0.00 \%$ & $0.00 \%$ & $-0.08 \%$ & $0.14 \%$ & $0.76 \%$ & $-0.22 \%$ \\
\hline Cosmetic items & $0.00 \%$ & $-0.01 \%$ & $0.00 \%$ & $0.00 \%$ & $0.00 \%$ & $-0.27 \%$ & $-0.02 \%$ & $0.00 \%$ & $-0.16 \%$ \\
\hline Air filter & $0.00 \%$ & $0.01 \%$ & $0.00 \%$ & $0.00 \%$ & $0.00 \%$ & $0.09 \%$ & $-0.01 \%$ & $0.00 \%$ & $0.42 \%$ \\
\hline $\begin{array}{l}\text { Limited time } \\
\text { and areas offer }\end{array}$ & $0.00 \%$ & $-0.04 \%$ & $0.00 \%$ & $0.00 \%$ & $0.00 \%$ & $-0.14 \%$ & $-0.02 \%$ & $0.02 \%$ & $0.12 \%$ \\
\hline Air cleaner & $0.00 \%$ & $-0.18 \%$ & $0.00 \%$ & $0.00 \%$ & $0.00 \%$ & $-0.04 \%$ & $0.01 \%$ & $0.12 \%$ & $-0.01 \%$ \\
\hline Smell good & $0.00 \%$ & $-0.09 \%$ & $0.00 \%$ & $0.00 \%$ & $0.00 \%$ & $-0.23 \%$ & $0.01 \%$ & $0.07 \%$ & $0.13 \%$ \\
\hline Floor cleaner & $0.00 \%$ & $0.00 \%$ & $0.00 \%$ & $0.00 \%$ & $0.00 \%$ & $0.07 \%$ & $0.02 \%$ & $0.01 \%$ & $0.03 \%$ \\
\hline Fire extinguisher & $0.00 \%$ & $-0.21 \%$ & $0.00 \%$ & $0.00 \%$ & $0.00 \%$ & $-0.01 \%$ & $0.03 \%$ & $0.14 \%$ & $-0.04 \%$ \\
\hline Plumbing product & $0.00 \%$ & $-0.01 \%$ & $0.00 \%$ & $0.00 \%$ & $0.00 \%$ & $-0.63 \%$ & $-0.21 \%$ & $-0.06 \%$ & $-0.28 \%$ \\
\hline Special cleaner & $0.00 \%$ & $0.00 \%$ & $0.00 \%$ & $0.00 \%$ & $0.00 \%$ & $0.00 \%$ & $0.00 \%$ & $0.00 \%$ & $0.00 \%$ \\
\hline Kitchen product & $0.00 \%$ & $0.00 \%$ & $0.00 \%$ & $0.00 \%$ & $0.00 \%$ & $0.00 \%$ & $0.00 \%$ & $0.00 \%$ & $0.00 \%$ \\
\hline Handy cleaner & $0.00 \%$ & $0.02 \%$ & $0.00 \%$ & $0.00 \%$ & $0.00 \%$ & $0.50 \%$ & $0.00 \%$ & $0.01 \%$ & $2.11 \%$ \\
\hline Living good & $0.00 \%$ & $-0.01 \%$ & $0.00 \%$ & $0.00 \%$ & $0.00 \%$ & $-0.20 \%$ & $-0.08 \%$ & $-0.01 \%$ & $0.26 \%$ \\
\hline Carpet & $0.00 \%$ & $0.49 \%$ & $0.00 \%$ & $0.00 \%$ & $0.00 \%$ & $0.07 \%$ & $0.03 \%$ & $0.23 \%$ & $0.18 \%$ \\
\hline \multirow[t]{2}{*}{$\begin{array}{l}\text { Bath and lavatory } \\
\text { good }\end{array}$} & $0.00 \%$ & $0.00 \%$ & $0.00 \%$ & $0.00 \%$ & $0.00 \%$ & $0.00 \%$ & $0.00 \%$ & $0.00 \%$ & $0.00 \%$ \\
\hline & $\begin{array}{l}\text { Trust of } \\
\text { products } \\
\text { and } \\
\text { services }\end{array}$ & $\begin{array}{l}\text { Recomme- } \\
\text { ndation }\end{array}$ & $\begin{array}{l}\text { Evaluation } \\
\text { from close } \\
\text { people }\end{array}$ & $\begin{array}{l}\text { Good } \\
\text { products, } \\
\text { although } \\
\text { expensive }\end{array}$ & $\begin{array}{l}\text { Focus on } \\
\text { convenience }\end{array}$ & $\begin{array}{l}\text { Focus on } \\
\text { service } \\
\text { after } \\
\text { purchase }\end{array}$ & $\begin{array}{l}\text { Decision } \\
\text { right to } \\
\text { low price }\end{array}$ & $\begin{array}{l}\text { Decision } \\
\text { right to high } \\
\text { price }\end{array}$ & $\begin{array}{l}\text { Enjoy with } \\
\text { family }\end{array}$ \\
\hline $\begin{array}{l}\text { OA products } \\
\text { cleaner }\end{array}$ & $-0.02 \%$ & $-0.03 \%$ & $-0.01 \%$ & $-0.01 \%$ & $-0.10 \%$ & $-0.09 \%$ & $0.00 \%$ & $0.00 \%$ & $-0.04 \%$ \\
\hline Gift & $0.52 \%$ & $0.42 \%$ & $0.16 \%$ & $0.12 \%$ & $0.00 \%$ & $0.05 \%$ & $0.00 \%$ & $0.00 \%$ & $1.80 \%$ \\
\hline Laundry good & $0.00 \%$ & $0.00 \%$ & $0.00 \%$ & $0.00 \%$ & $0.00 \%$ & $0.00 \%$ & $0.00 \%$ & $0.00 \%$ & $0.00 \%$ \\
\hline Water cleaner & $-0.13 \%$ & $-1.36 \%$ & $-0.40 \%$ & $-0.21 \%$ & $-9.72 \%$ & $-0.27 \%$ & $0.00 \%$ & $0.00 \%$ & $-0.05 \%$ \\
\hline Cosmetic items & $-0.51 \%$ & $-0.49 \%$ & $-1.83 \%$ & $-0.89 \%$ & $-0.07 \%$ & $-0.04 \%$ & $0.00 \%$ & $0.00 \%$ & $-0.02 \%$ \\
\hline Air filter & $0.06 \%$ & $0.01 \%$ & $0.01 \%$ & $0.02 \%$ & $0.00 \%$ & $-0.01 \%$ & $0.12 \%$ & $0.23 \%$ & $2.66 \%$ \\
\hline $\begin{array}{l}\text { Limited time and } \\
\text { areas offer }\end{array}$ & $-0.09 \%$ & $-0.23 \%$ & $-0.08 \%$ & $-0.06 \%$ & $-0.51 \%$ & $-0.50 \%$ & $0.03 \%$ & $0.05 \%$ & $0.33 \%$ \\
\hline Air cleaner & $-0.03 \%$ & $-0.28 \%$ & $-0.08 \%$ & $-0.05 \%$ & $-1.63 \%$ & $-0.08 \%$ & $0.01 \%$ & $0.02 \%$ & $0.22 \%$ \\
\hline
\end{tabular}


(Table 17 continued)

\begin{tabular}{|c|c|c|c|c|c|c|c|c|c|}
\hline Smell good & $-0.19 \%$ & $-0.32 \%$ & $-0.12 \%$ & $-0.09 \%$ & $-1.22 \%$ & $-1.14 \%$ & $0.00 \%$ & $0.00 \%$ & $-0.49 \%$ \\
\hline Floor cleaner & $0.03 \%$ & $0.12 \%$ & $0.05 \%$ & $0.03 \%$ & $0.02 \%$ & $0.04 \%$ & $0.00 \%$ & $0.00 \%$ & $0.04 \%$ \\
\hline Fire extinguisher & $-0.03 \%$ & $-0.26 \%$ & $-0.07 \%$ & $-0.04 \%$ & $-1.85 \%$ & $-0.05 \%$ & $0.00 \%$ & $0.00 \%$ & $-0.01 \%$ \\
\hline Plumbing product & $-0.25 \%$ & $-1.11 \%$ & $-0.40 \%$ & $-0.28 \%$ & $-0.14 \%$ & $-0.34 \%$ & $0.00 \%$ & $0.00 \%$ & $-0.36 \%$ \\
\hline Special cleaner & $0.00 \%$ & $0.00 \%$ & $0.00 \%$ & $0.00 \%$ & $0.00 \%$ & $0.00 \%$ & $0.00 \%$ & $0.00 \%$ & $0.00 \%$ \\
\hline Kitchen product & $0.00 \%$ & $0.00 \%$ & $0.00 \%$ & $0.00 \%$ & $0.00 \%$ & $0.00 \%$ & $0.00 \%$ & $0.00 \%$ & $0.00 \%$ \\
\hline Handy cleaner & $0.31 \%$ & $0.19 \%$ & $0.13 \%$ & $0.13 \%$ & $-0.11 \%$ & $-0.08 \%$ & $0.59 \%$ & $1.13 \%$ & $12.97 \%$ \\
\hline Living good & $-0.07 \%$ & $-0.46 \%$ & $-0.16 \%$ & $-0.10 \%$ & $-0.25 \%$ & $-0.31 \%$ & $0.10 \%$ & $0.19 \%$ & $1.96 \%$ \\
\hline Carpet & $0.03 \%$ & $0.75 \%$ & $0.22 \%$ & $0.12 \%$ & $4.22 \%$ & $10.70 \%$ & $0.00 \%$ & $0.00 \%$ & $-0.11 \%$ \\
\hline \multirow[t]{2}{*}{$\begin{array}{l}\text { Bath and lavatory } \\
\text { good }\end{array}$} & $0.00 \%$ & $0.00 \%$ & $0.00 \%$ & $0.00 \%$ & $0.00 \%$ & $0.00 \%$ & $0.00 \%$ & $0.00 \%$ & $0.00 \%$ \\
\hline & $\begin{array}{l}\text { Explaining } \\
\text { how to use } \\
\text { products } \\
\text { and } \\
\text { services }\end{array}$ & $\begin{array}{l}\text { Delivery } \\
\text { service }\end{array}$ & $\begin{array}{l}\text { One-point } \\
\text { lesson }\end{array}$ & $\begin{array}{l}\text { Organisat } \\
\text {-ion } \\
\text { lecture }\end{array}$ & $\begin{array}{l}\text { Communic- } \\
\text { ation based } \\
\text { on daily } \\
\text { conversation }\end{array}$ & $\begin{array}{l}\text { Communic } \\
\text {-ation } \\
\text { based on } \\
\text { sales } \\
\text { products }\end{array}$ & $\begin{array}{l}\text { Communic } \\
\text {-ation } \\
\text { based on } \\
\text { new } \\
\text { products }\end{array}$ & $\begin{array}{l}\text { Number of } \\
\text { preschool } \\
\text { children }\end{array}$ & $\begin{array}{l}\text { Number of } \\
\text { elementary } \\
\text { and junior } \\
\text { high school } \\
\text { students }\end{array}$ \\
\hline $\begin{array}{l}\text { OA products } \\
\text { cleaner }\end{array}$ & $-0.16 \%$ & $-0.05 \%$ & $-1.00 \%$ & $-0.52 \%$ & $0.02 \%$ & $0.00 \%$ & $0.00 \%$ & $-0.09 \%$ & $0.04 \%$ \\
\hline Gift & $6.33 \%$ & $1.89 \%$ & $1.01 \%$ & $2.03 \%$ & $0.00 \%$ & $0.00 \%$ & $0.07 \%$ & $0.37 \%$ & $-0.16 \%$ \\
\hline Laundry good & $0.00 \%$ & $0.00 \%$ & $0.00 \%$ & $0.00 \%$ & $0.00 \%$ & $0.00 \%$ & $0.00 \%$ & $0.00 \%$ & $0.00 \%$ \\
\hline Water cleaner & $-0.19 \%$ & $-0.09 \%$ & $-2.14 \%$ & $-0.61 \%$ & $2.13 \%$ & $0.02 \%$ & $0.00 \%$ & $-0.11 \%$ & $0.12 \%$ \\
\hline Cosmetic items & $-0.04 \%$ & $-0.14 \%$ & $-0.02 \%$ & $-0.02 \%$ & $0.01 \%$ & $0.00 \%$ & $-0.07 \%$ & $-0.02 \%$ & $0.01 \%$ \\
\hline Air filter & $0.65 \%$ & $0.04 \%$ & $0.09 \%$ & $0.17 \%$ & $0.00 \%$ & $0.00 \%$ & $0.01 \%$ & $-0.18 \%$ & $0.07 \%$ \\
\hline $\begin{array}{l}\text { Limited time and } \\
\text { areas offer }\end{array}$ & $-0.78 \%$ & $-0.74 \%$ & $-4.97 \%$ & $-2.60 \%$ & $0.10 \%$ & $0.00 \%$ & $-0.01 \%$ & $-0.51 \%$ & $0.22 \%$ \\
\hline Air cleaner & $-0.06 \%$ & $-0.24 \%$ & $-0.58 \%$ & $-0.22 \%$ & $0.36 \%$ & $0.00 \%$ & $0.00 \%$ & $-0.06 \%$ & $0.04 \%$ \\
\hline Smell good & $-1.96 \%$ & $-0.67 \%$ & $-12.25 \%$ & $-6.37 \%$ & $0.25 \%$ & $0.00 \%$ & $-0.02 \%$ & $-1.15 \%$ & $0.49 \%$ \\
\hline Floor cleaner & $0.14 \%$ & $0.55 \%$ & $0.03 \%$ & $0.05 \%$ & $0.00 \%$ & $0.00 \%$ & $0.00 \%$ & $0.01 \%$ & $0.00 \%$ \\
\hline Fire extinguisher & $-0.04 \%$ & $-0.02 \%$ & $-0.41 \%$ & $-0.12 \%$ & $0.41 \%$ & $0.00 \%$ & $0.00 \%$ & $-0.02 \%$ & $0.02 \%$ \\
\hline Plumbing product & $-1.27 \%$ & $-4.93 \%$ & $-0.23 \%$ & $-0.42 \%$ & $-0.01 \%$ & $-0.01 \%$ & $-0.04 \%$ & $-0.07 \%$ & $0.04 \%$ \\
\hline Special cleaner & $0.00 \%$ & $0.00 \%$ & $0.00 \%$ & $0.00 \%$ & $0.00 \%$ & $0.00 \%$ & $0.00 \%$ & $0.00 \%$ & $0.00 \%$ \\
\hline Kitchen product & $0.00 \%$ & $0.00 \%$ & $0.00 \%$ & $0.00 \%$ & $0.00 \%$ & $0.00 \%$ & $0.00 \%$ & $0.00 \%$ & $0.00 \%$ \\
\hline Handy cleaner & $3.18 \%$ & $0.94 \%$ & $-0.64 \%$ & $0.33 \%$ & $0.02 \%$ & $0.00 \%$ & $0.04 \%$ & $-0.97 \%$ & $0.39 \%$ \\
\hline Living good & $-0.25 \%$ & $-1.91 \%$ & $-1.93 \%$ & $-1.01 \%$ & $0.04 \%$ & $0.00 \%$ & $-0.01 \%$ & $-0.35 \%$ & $0.15 \%$ \\
\hline Carpet & $-0.46 \%$ & $0.70 \%$ & $-2.48 \%$ & $-1.51 \%$ & $-0.65 \%$ & $0.06 \%$ & $0.04 \%$ & $-0.27 \%$ & $0.13 \%$ \\
\hline $\begin{array}{l}\text { Bath and lavatory } \\
\text { good }\end{array}$ & $0.00 \%$ & $0.00 \%$ & $0.00 \%$ & $0.00 \%$ & $0.00 \%$ & $0.00 \%$ & $0.00 \%$ & $0.00 \%$ & $0.00 \%$ \\
\hline
\end{tabular}

Table 17 reveals the significant differences in purchase probability, as evidenced by the questionnaire "Do you want products that can delightfully clean with family?", as "delight with family"/"elow" falls under the condition between "high" and "low" (answer: "high", "low"). The results are illustrated in Figure 9, a graph noting the purchase probabilities for combinations of service provider type $\mathrm{D}$ and customer type 3 , and in Figure 10, which displays a graph of the purchase probabilities for service provider A in combination with service provider type D and customer type 3 . 


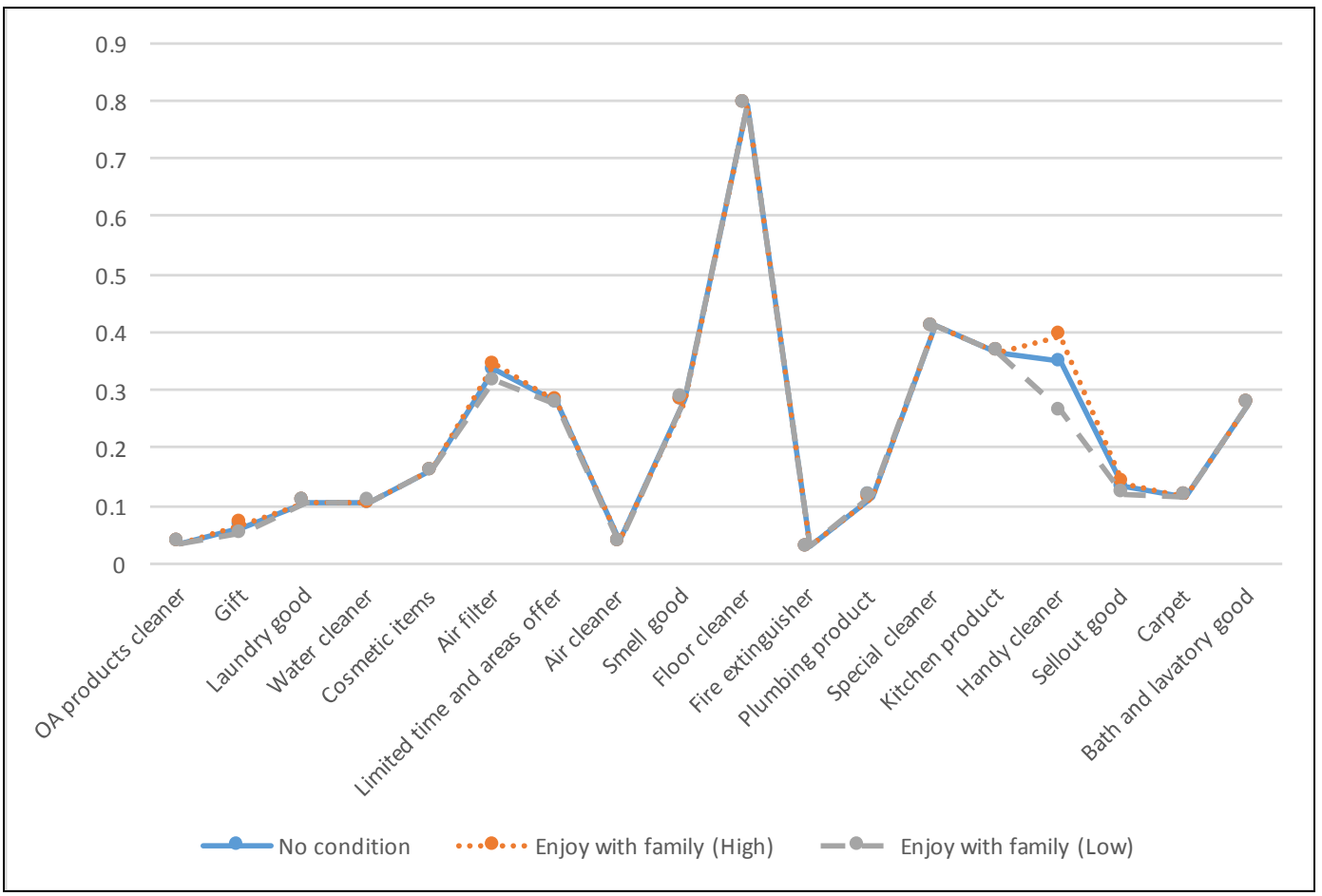

Figure 9. Purchase probabilities of $\mathrm{spD} / \mathrm{cu} 3$ type.

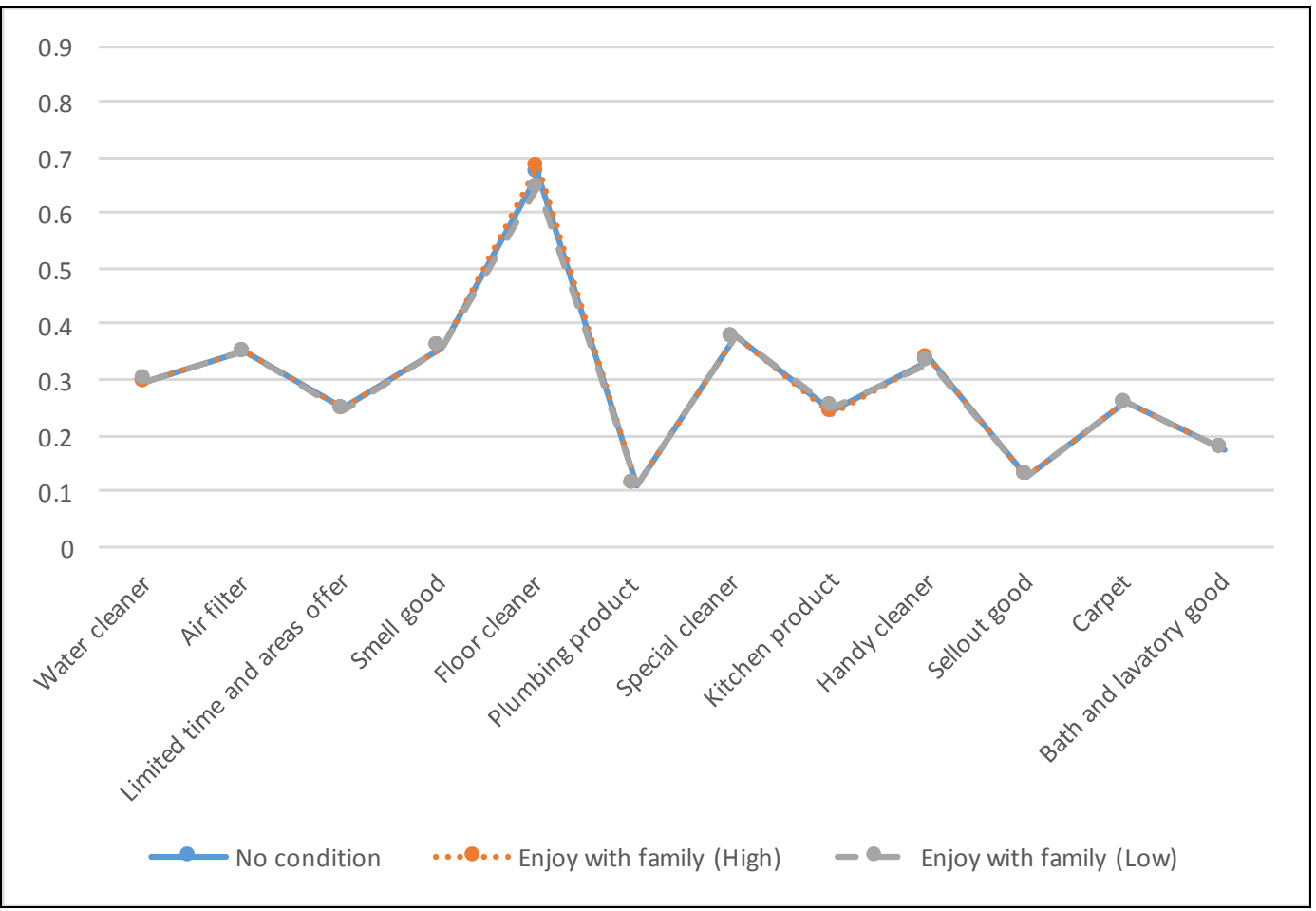

Figure 10. Purchase probabilities of service provider A in $\mathrm{spD} / \mathrm{cu} 3$ type.

Figure 9 displays the significant differences in the purchase probabilities of a handy cleaner, as conditioned by the question involving "delight with family?", which is characteristic of the combination of $\mathrm{spD} / \mathrm{cu} 3$. This is because they are raising children, and may perceive the handy cleaner as easy for cleaning that 
involves children. Therefore, the handy cleaner has sold well. However, the analysis results with service provider A do not parallel the above. It can be recommended that service provider A recommend the handy cleaner to the customer that answers "high" in the question "delight with family?".

An analysis method to support service provider sales behaviours in presenting effective products categories is proposed. The recommended product categories are effective for each customer, and are led by analysing customers' questionnaire data and purchase history.

Phase 1: Classify service providers and customers into types. Construct a purchasing Bayesian network with each combination of service provider and customer type.

Phase 2: Predict the purchase probabilities from stochastic reasoning, based on the structured purchasing Bayesian network constructed in Phase 1.

Phase 3: Display recommended product categories in each combined type.

Phase 4: Construct a purchasing Bayesian network by service provider, in belonging to the service provider type.

Phase 5: Predict the purchase probabilities from stochastic reasoning, based on structured purchasing Bayesian network as constructed in Phase 4.

Phase 6: Compare this to the results of differences in the purchase probabilities from stochastic reasoning in Phases 2 and 5. When a service provider cannot sell the products sold by other service providers in the type, the service provider will be supported with a recommended customer list.

\section{Conclusion}

This study clustered service providers and customers into types by their questionnaire survey answers about a sense of values, needs, and abilities. Purchase characteristics were then discussed as modelled by each combined-type Bayesian network, which were constructed of customer purchase history and questionnaire survey data. The variables were extracted as hubs in each combination type, and points were revealed that service providers must address to meet their customers' needs. Hubs among combinations of customer and service provider types were compared and discussed. Further, stochastic reasoning predictions were indicated in structured purchase Bayesian network models as levels of customer questionnaire survey variables were set as conditions, and set the level of product category variables as objects. As a result, the difference in purchase probability with "high" and "low" levels is calculated in each type. Moreover, the purchasing Bayesian network model in each service provider in the type was structured, and the purchase probability for the service provider was predicted using stochastic reasoning. Finally, the differences between the purchase probabilities under "high" and "low" conditions for all service providers in the service provider type were compared with those

differences for service provider A in the type. It was proposed that a support system could improve service providers' sales skill by submitting recommendations for appropriate customers when there is a small difference in the purchase probabilities for the service provider in the type in comparison with those for all the number of the type.

\section{References}

Anderson, E. W., Fornell, C., \& Rust, R. T. (1997). Customer satisfaction, productivity, and profitability: Differences between goods and services. Marketing Science, 16(2), 129-145.

Gąsior, M., Skowron, Ł., \& Sak-Skowron, M. (2014). Multidimensional structure of employee motivation-Clustering approach. AIP Conference Proceedings, 1635(1), 754(Icoqsia), 748-754. 
Grönroos, C. (1990). Service management and marketing: Managing the moment of truth in service competition. Lexington Books.

Hultman, J., \& Ek, R. (2011). Can there only be one? Towards a post-paradigmatic service marketing approach. International Journal of Quality and Service Sciences, 3(2), 166-180.

Imoto, S. (2011). Statistical science of the 21th century. Japan Statistical Society HP version, 2, 141-168.

Ono, Y., \& Shoji, I. (2015). Senior-Junior (Senpai-Kohai) relationships in secondary school activities. The Japanese Association of Educational Psychology, 63(4), 438-452.

Shinkawa, H., Shimada, M., Hayase, M., \& Inui, T. (2009). A survey of the variety, incidence rate, and frequency of minor symptoms currently experienced by expectant mothers. Japan Academy of Midwifely, 23(1), 48-58.

Watabe, H., \& Tsubaki, M. (2016). A study on the matching between customers and service providers using the system for analyzing the effects of the service by customer type. The Japan Society for Management Information, 24(4), 231-238.

Zeithaml, V. A., Berry, L. L., \& Parasuraman, A. (1993). The nature and determinants of customer expectations of service. Journal of the Academy of Marketing Science, 21(1), 1-12.

Zeithaml, V. A., Bitner, M. J., \& Gremler, D. D. (2010). Services marketing strategy. Wiley International Encyclopedia of Marketing Part 1: Marketing Strategy, 1(May), 208-218.

Zeithaml, V. A., Parasuraman, A., \& Berry, L. L. (1985). Problems and services strategies in marketing. Journal of Marketing, 49(2), 33-46. 